\title{
Urban Planning and European Innovation Policy: Achieving Sustainability, Social Inclusion, and Economic Growth?
}

\author{
Kim Carlotta von Schönfeld ${ }^{1, *}$ (D) and António Ferreira ${ }^{2}$ (D) \\ 1 Department of Environmental Sciences, Wageningen University, 6708 PB Wageningen, The Netherlands \\ 2 CITTA-Centre for Research on Territory, Transports and Environment, University of Porto, \\ 4200-465 Porto, Portugal; acf@fe.up.pt \\ * Correspondence: kim.vonschonfeld@wur.nl or kcvschoenfeld@posteo.net
}

Citation: von Schönfeld, K.C.; Ferreira, A. Urban Planning and European Innovation Policy: Achieving Sustainability, Social Inclusion, and Economic Growth? Sustainability 2021, 13, 1137. https://doi.org/10.3390/ su13031137

Academic Editor: Goran Roos

Received: 5 November 2020

Accepted: 16 January 2021

Published: 22 January 2021

Publisher's Note: MDPI stays neutral with regard to jurisdictional claims in published maps and institutional affiliations.

Copyright: (c) 2021 by the authors. Licensee MDPI, Basel, Switzerland. This article is an open access article distributed under the terms and conditions of the Creative Commons Attribution (CC BY) license (https:/ / creativecommons.org/licenses/by/ $4.0 /)$.

\begin{abstract}
Innovation has become a guiding principle for European Union policy. Funding schemes, research, and planning across all Member States are expected to be innovative. This article provides a critical analysis of the drivers and effects of this evolution. While positive results have been achieved due to innovation policies, this article proposes that taking a wider critical perspective reveals important caveats. The article zooms in on the EU's innovation policies by analysing policy documents, projects funded, and on-the-ground impact on three citizen initiatives. The analysis asks whether and how the EU's self-set goals of sustainability, social inclusion, and economic growth are approached and met in them. The findings suggest a problematic funnelling process. First, an emphasis on innovation is created with the objective of systematically unblocking resistance to the development and implementation of novelties in the name of competitiveness, job creation, and economic growth. Second, the idea of innovation is very loosely defined, while, when translated into urban planning, it is interpreted narrowly in terms of efficiency and behavioural change, digitalization, and smart technologies. As a result, (narrowly defined) innovation-led economic growth begins to supersede alternative values and visions for the future of European cities and regions. This can represent a problem for EU Member States as it creates a very limited, risk-based, and divisive direction of development. To contribute to the (re-)establishment of alternatives, this article finally offers policy recommendations primarily concerned with the reinstatement of the public interest beyond innovation-centred planning perspectives.
\end{abstract}

Keywords: innovation; European Union; urban planning; social inclusion; sustainability; economic growth

\section{Introduction}

"The salesmen, before I had announced the policy, were spurred by the great sales to think that even greater sales might be had if only we had more models. It is strange how, just as soon as an article becomes successful, somebody starts to think that it would be more successful if only it were different. There is a tendency to keep monkeying with styles and to spoil a good thing by changing it." - Henry Ford [1]

The notion of innovation has found a stronghold in contemporary European policy, where it is frequently argued that innovation is a key promoter of a variety of desired outcomes such as sustainability, social inclusion, and economic growth [2-10]. Funding is increasingly channelled through European innovation policies, which thereby become the chief shapers of initiatives across Europe. However, an emerging body of critical scholarly work highlights the drawbacks of innovation, of its use as a principle, and of its role in policy guidance. Such critical authors argue that innovation can lead to environmental degradation, precarity, learning deficits, the dismantling of desirable societal and technological configurations, stress, and anxiety, among other possibilities (see, e.g., [10-19]). This raises the question of whether innovation-centred policy making achieves the goals it has set itself (i.e., sustainability, social inclusion, and economic growth). 
Exploring this question covers a research gap that is particularly relevant within the context of contemporary urban planning. Planning literature is typically aligned with policy approaches capable of promoting innovation, often relating it to inclusive, sustainable, co-creative practices (see, e.g., [8,20-22]). However, to date, this literature has dedicated limited attention to the question of why innovation has gained such a prominent role in planning and beyond (a recent welcome exception is provided by Hagen and Higdem [21], however, their approach remains focused on planning theory in particular, and does not adopt a critical perspective). Likewise, this literature did not yet explore in great detail the shortcomings of innovation as a guiding policy-making principle, despite a burgeoning branch of literature-namely within innovation studies-taking a quite critical stance towards dominant understandings of innovation $[12,23,24]$. As we shall discuss, the emergence of innovation is an intriguing process, particularly when considering its increasing presence in EU policy (see also [11,13]). Furthermore, the drawbacks are relatively counterintuitive to today's Zeitgeist. For these reasons, the main aim of this article is to expose potential drawbacks of innovation policy within the field of planning, and proposing potential alternatives, thereby addressing the above-described research gap. The article takes an explicit focus on EU innovation policy discourse, on the planning projects these have funded, and on how the emerging logic can affect small-scale initiatives on the ground.

This article explores the question of whether innovation policies achieve their own goals of sustainability, social inclusion, and economic growth within the context of planning. It does so by providing a historical perspective and academic background on innovation, followed by three empirical explorations. First, a critical discourse analysis of formulations of concepts, entities, and operationalizations used throughout relevant EU policy documents is presented, resulting in an EU innovation lexicon. Second, a critical analysis of twenty-one urban planning related projects funded and supported by the EU based on their innovative qualities is offered. Third, the scrutiny of one local illustration from Germany and another from the Netherlands is carried out to expose potential perversities that an innovation-oriented policy framework can produce in planning practice, and to facilitate future policies to avoid similar pitfalls. Finally, the article moves on to explore how the findings answer the question of whether, and how, innovation policies reach their own proposed goals, and what the consequences might be of failures to do so. Here, it also sketches possible alternatives to an innovation discourse through which policy could be informed.

\section{Historical and Scientific Background of Innovation in the EU}

The notion of innovation has a highly versatile history, as recounted by Godin ([25], see also [13] for an extended version of this historical perspective, and [26]). As Godin shows, innovation was first understood as a heresy capable of leading to political persecution around 1600s Europe. Innovation was seen for centuries as something that should be avoided or, at least, denied in public. This was gradually followed by the association of innovation with revolution and then with social reformation, and thus associated with progressive action. In these phases, innovation had a negative connotation in mainstream circles-a mainstream that was about conserving tradition while discouraging change and progress. A more positive connotation for innovation emerged only in the 1960s: at this stage, innovation became a means to promote economic prosperity through technological novelties [25]. In this phase, an increasingly sophisticated theoretical interpretation around the concept also emerged, "to understand and explain (revolutionary) changes through innovation and how governments may help" ([25], p. 52). This was followed, finally, since the 1980s, by an increasing understanding of innovation as an end in itself rather than (only) a means. In this last stage, innovation started to be rewarded and even celebrated.

In scientific literature, the concept took a similar trajectory, as Godin also recounts in detail [25]. Accordingly, recent scientific literature on innovation focuses on exploring details of how innovation works, accepting as a given that it is a desirable or simply existing goal (see e.g., [20,27-32]). Several renowned academic journals have "innovation" in their 
titles (e.g., the Journal of Innovation \& Knowledge, the Journal of Innovation and Entrepreneurship, Innovation, and many others). In the social sciences, a trend has emerged in relation to "social innovation", heralding the need to bring the idea of support for, and studies of, innovation specifically into studies on inequalities and social sustainability $[8-10,33,34]$. In the arts, there is awareness of critical voices on innovation, and yet there is a struggle to understand art as non-innovative [17]. In planning, as part of the social sciences but with a direct rapport to applied practice, the currently dominant approach is that of taking the positive meaning of innovation as a given and studying ways in which it can be achieved, or how it can be implemented properly-because when there are imperfections in applications, this is seen not as a problem with the innovation paradigm, but with the ways it has been applied. This is confirmed through a systematic review of articles including the term "innovation" in their title published between 2015 and 2020 in key planning journals, as presented in Appendix A. The exceptions, as shown, remain a minority, though they tend to be the more recent ones, and thus might indicate a trend in the direction of more critical perspectives. Critical voices on innovation have begun to emerge, mainly in fields outside of planning, as has also been mentioned above [10-19]. This can perhaps be seen as a hint that a subsequent phase to those described in Godin's historical account may be developing. We hope to contribute to this via this article specifically within the field of planning, but also as a contribution to this wider trend of critically reviewing the meaning and benefits of innovation policy. We now turn to a historical account of how innovation has been understood in the European Union, especially in its policy documents and justifications for funding schemes, while seeking a relation to the historical events that may have impacted how and why this understanding of innovation took such a path. Sometimes, scientific developments were a part of this.

The European Union's (EU's) history is also closely aligned with Godin's account. The EU was conceived as a follow-up to the European Coal and Steel Community (ECSC; $1951)$ and the European Economic Community (EEC; 1957) which had been set up for the conservation of peace and reconstruction of economic prosperity in Europe after World War II (WWII). The EU aligned itself with innovation only in the early 1990s in its Treaty of Maastricht [35], where innovation was mentioned in relation to industry in particular. Innovation was referred to more broadly in the Treaty of Lisbon [36], where it was seen as a means to achieve economic growth, which, in turn, was seen as-and continues to be-a key goal of the EU and its Member States. This latest Treaty of Lisbon also closely linked the promotion of innovation to the maintenance of price stability. How this manifested in contemporary policies will be explored further below.

To start with, it is important to look at the broader context of the second half of the twentieth century, in which the notion of innovation as an intrinsically positive societal value gradually took root. For example, calls for progress and change became increasingly mainstream in Western Europe and in the USA gradually after WWII, and with the maturation of the generation following this war as those that aimed to reform the societal order so that the mistakes of the past would not be repeated. This became particularly prominent during the 1960s and 1970s, possibly experiencing its climax in 1968. Social and feminist movements asked for meaningful changes in the fabric of society while a consensus emerged in Western Europe that the old status quo could no longer be supported due to the terrible consequences it had allowed. This was especially the case in post-WWII Germany, though several other European countries experienced similar processes as they increasingly rebuked themselves for their colonial pasts. Note also that, with the emergence and consolidation of the Cold War as a key shaper of world politics, both the USA and USSR developed a strong interest in technological innovations to demonstrate to each other their own military, but also ideological and civilizational, superiority. The race to space and to the Moon is a clear example of that power struggle, where capitalism and communism fought against each other to show their loftier abilities to innovate. This race to the Moon is something that today the European Union is presenting as a key inspiration for its Mission-Oriented Research and Innovation concept [2] - a revealing example of the 
twentieth century historical legacy influencing present-day policies. Indeed, the end of the Cold War did not represent the end of innovation-driven development. On the contrary, as it resulted in the global triumph of the capitalist logic, innovation became more mainstream than ever as a means to achieve competitiveness, profits, and economic growth. In the late 1980s, the Brundtland report [37] added the urgencies of sustainability and $\mathrm{CO}_{2}$ emissions to the mainstreamed list of things that required urgent structural changes to the status quo.

It was unsurprising that calls for change abounded in such a historical context where social justice and environmental sustainability were seen as evidently lacking. Change through innovation, understood as the introduction of something new and positive, became increasingly accepted and mainstreamed. At first, technological solutions were prioritized, but as this was proven to be insufficient or insufficiently fast, the notion of "social innovation" was reinvigorated around the 2000s (the notion had existed conceptually since the early 19th century [25]). This was based on at least two arguments. First, that technological innovation did not sufficiently address societal issues and was, therefore, doomed to fail its objectives of achieving sustainability, social inclusion, and economic growth, but especially social inclusion (see [8]). Second, that "experts" could not innovate enough for sustainability and social justice to finally prevail, and so the inclusion of "lay knowledge" and "citizens" in decision-making and innovation processes was considered paramount - see, for example, the move from a triple helix innovation model (that is, one resulting from the intertwining of universities, industry, and government) as conceptualized by authors such as Etzkowitz ([38], see also [39] and [40]), to the quadruple helix model (that is, one resulting from the collaborations among universities, industry, government, and citizens) [41-43].

Social innovation was considered "social" in both its means and ends. For example, Moulaert et al. [8] wrote that social innovation is about "addressing problems, improving the human condition, satisfying the needs of humans, setting agendas for a better future." Overall, then, innovation was gradually perceived as the key (if not only) solution to the tension between economic growth on the one hand, and sustainability and social justice on the other. This tension was highlighted in the document "The Limits to Growth" [44] and the Brundtland report [37], as well as in more recent high-impact publications [45,46].

As these perceptions on sustainability, social inclusion, economic growth, and innovation became increasingly mainstream, the more unnecessary it seemed to discuss them. These concepts became depoliticized through their dominant use and mainstreaming. They became the immutable backdrop to constantly changing scenes and vocabularies, proposing commodification processes and immediate market-oriented technological solutions even when the problems they were supposed to solve were unclear or not actually solved [47]. This made buzzwords the order of the day and increased the speed of innovation to unprecedented levels [47-50]. From this backdrop, the EU solidified and expanded its conception of innovation-enabled economic growth through homogenization across the European continent. As a partial result of this, there is increasingly less discussion of what constitutes the public interest [51] and what are the desirable traits of contemporary societies. Through this, the innovation discourse became repetitive and difficult to change-an interesting paradox. In the meantime, large companies (namely "Big Tech") are encouraged to prosper in the name of innovation, progress, and economic growth despite their incursions on privacy, legality, and democracy [52,53]. As a result, economies, cities, companies, factories, and start-ups all became spaces for innovation [54]. The EU, without diverging from its core objective of economic growth, expanded its authority throughout virtually all areas of public and private European life, as all are seen as potential enablers of economic expansion-a common feature of contemporary economic discourse, despite the historical warnings against doing so [55]. For examples of this broadening of European intervention areas, see the EU's list of 291 policies, which comprise subjects as diverse as animal diseases; asylum; economics of sports; GMOs [i.e., Genetically Modified Organisms]; semen, ova, embryos; tobacco; and youth [56] and its latest six "goals" (see [57]), all framed within the logic of economic growth, and all thus with the potential to be innovated upon. 
In summary, the EU embraced a task of such complexity and reach that ingenious novelties seem to be the only tools to deliver it. The increasingly prominent role of innovation as a meta-goal of European public policy [58] becomes understandable as the EU became concerned with an increasing number of policy areas, while simultaneously seeing economic growth as well as environmental sustainability as key goals. As is shown below in the lexicon, the idea of innovation is presented as necessary even when precautionary regulations advise against it.

\section{Methods}

The methods adopted to review the EU policies on innovation had a three-fold objective:

- to uncover what the term "innovation" means in EU policy and how it relates to the goals of sustainability, economic growth, and social inclusion;

- how innovation is used in identifying and supporting initiatives and research throughout the EU;

- what a critical eye on the implementation of local policies driven by the European innovation logic can reveal.

The first and second steps were approached through a subject-specific systematic review and discourse analysis, and the third through empirical materials. The methods are described in detail below.

First, the EU innovation discourse is critically analysed through the compilation of a lexicon of terms related with innovation used by the European Commission, the European Parliament, and related organizational strands (e.g., Eurostat). Such a discourse analysis aims to uncover the ways in which the particular language is used to describe and define innovation and related concepts. This is done under the premise of discourse analysis that such language reflects but also constructs realities by affecting what is included and which elements are given power (and which not) in relation to a given subject [59]. Therefore, a systematic search of the innovation-specific policies of the EU was conducted, followed by a snowballing process based on the key terms and instruments introduced. The baseline definition of each concept, entity, or operationalization was then sought throughout the respective policy documents, factsheets, and websites. The lexicon makes use of extensive quotations to fully expose and critically analyse the line of argumentation and word-choice employed by the EU (for methodological background on this textual analysis as a part of discourse analysis, see Bryman [59], pp. 528-540).

Second, a number of EU-funded projects meant to generate innovations were systematically identified through the "Innovation Radar" of the EU (www.innoradar.eu; date of search: 6 October 2020). Since over six thousand such projects are covered through the Radar, the search words "urban planning" were used to narrow the possibilities down to thirty-three innovations introduced by twenty-one projects. Some projects developed several innovations, in which case the project's description was used only once. The key objectives of each selected project were analysed. The analysis looked for whether the promoted objective of the project was one of the following:

- sustainability,

- social inclusion,

- economic growth,

and which of the following mechanisms were used for achieving those objectives, if any:

- efficiency,

- digitalization and "smart" technologies,

- behavioural change.

These objectives and mechanisms emerged deductively through the theoretical discussion above and from the lexicon, as well as inductively by checking whether any other dominant objectives and mechanisms would emerge in the analysis. Though other objectives and mechanisms did appear occasionally in some projects, this was very rare, and the projects still had strong similarities with the remaining ones (for example, the 
specific objective of "safety from terrorism" is named in one of the projects. However, its mechanism, as with most other projects, is that of digitalization and "smart" technologies. It also aligns itself explicitly with the objective of economic growth, which is noted as the promoted objective in the analysis. See also results below). In line with the discourse analytic goal of this article, quotations of the project descriptions are included in Appendix B, and reflections on certain word choices are included in the analysis in Section 4.2.

Third, next to these methods of analysing EU-supported innovation projects, two illustrations of problematic effects of the EU's innovation policy in planning practice are presented. First, an illustration of two competing initiatives to increase the mobility of the elderly in a Dutch city. This illustration is based on a case study conducted by the lead author between 2016 and 2020, including longitudinal participatory observation and ten in-depth interviews with initiators and a local government official. This case is kept anonymous to protect the privacy and future funding opportunities of the participants and initiatives. The second illustration is based on a German case study from a secondary source [16]. Both illustrations concern initiatives that provide significant contributions in the areas of sustainability and social inclusion, and could affect economic growth through job creation and by helping long-term unemployed persons to find a way back into the labour market-a perhaps small but locally significant contribution to economic stability and/or growth. The two illustrations are presented and analysed in terms of how innovation policy affected their opportunities for implementation and maintenance of their idea. Thereby, they help to ground the findings from the lexicon and Innovation Radar results in local everyday planning experiences. The illustrations do not deny that other cases may demonstrate positive effects of the same policies, but rather aim to expose possible mechanisms through which innovation policies can have counter-productive effects.

\section{Analysis}

By way of introduction to the analysed material, a contextual overview of the EU's recent and current policies is presented. The 2019-2024 European Commission (EC) priorities are listed as [60]:

- “A European Green Deal: Europe aims to be the first climate-neutral continent by becoming a modern, resource-efficient economy

- A Europe fit for the digital age: The EU's digital strategy will empower people with a new generation of technologies

- An economy that works for people: The EU must create a more attractive investment environment, and growth that creates quality jobs, especially for young people and small businesses

- A stronger Europe in the world: The EU will strengthen its voice in the world by championing multilateralism and a rules-based global order

- Promoting our European way of life: Europe must protect the rule of law if it is to stand up for justice and the EU's core values

- A new push for European democracy: We need to give Europeans a bigger say and protect our democracy from external interference such as disinformation and online hate messages."

The design of these priorities is strongly influenced by the "innovation principle" (see below) which is presented as transversal to all policy areas [61,62]. Innovation threads throughout the EU's structures and policies, as is shown in detail below. Furthermore, as the "Research and Innovation" page of the European Union [63] highlights, "Research, science and innovation have been placed at the heart of the EU's strategy to create growth and jobs. Boosting this area will help find solutions to our biggest societal challenges-such as climate change, energy security and public health—as well as make Europe a better place to live and work." 


\subsection{A European Innovation-Based Lexicon}

In this subsection, we present the definitions of commonly used innovation terminology in EU policy documents. We begin with key concepts, followed by the entities associated with these concepts, and finally present operationalizations (including methods, frameworks, and tools for implementation) of the innovation concepts in EU policy. Throughout, a number of quotes include emphasized sections in bold so as to facilitate the discussion of certain recurring themes at the end of the lexicon.

\subsubsection{Concepts}

\section{Innovation}

Within EU documents, innovation is not formally defined (see also [23]), though it is always understood in terms of new ideas, products, or methods. In some documents, innovations are presented as simply something new, but in most cases, they are directly considered as something that provides an improvement (usually not specifying for whom). Innovation is often combined with other words to distinguish concepts, such as technological versus social innovation or product versus process innovation. The term innovation is sometimes used interchangeably with "open innovation" on EU websites, without clear reference to the meaning of "open" in these cases (see Lorne [54] for a critical review of the trend to speak of "openness" in this sense-he highlights the ways through which this contributes to neoliberalization). A few quotes from EU websites and documents help to illustrate:

Eurostat [64]: "Innovation is the use of new ideas, products or methods where they have not been used before. For the Community Innovation Survey (CIS), an innovation is defined as a new or significantly improved product (good or service) introduced to the market, or the introduction within an enterprise of a new or significantly improved process."

European Parliament [65]: "Innovation plays an increasing role in our economy. It provides benefits for citizens as both consumers and workers. It is essential to creating better jobs, building a greener society and improving our quality of life, but also to maintaining EU competitiveness in the global market. Innovation policy is the interface between research and technological development policy and industrial policy and aims to create a conducive framework for bringing ideas to market."

Agricultural European Innovation Partnership [66]: "Innovation in the agricultural and forestry sector is a broad subject, but in general terms can be described as 'a new idea that proves successful in practice'. In other words, the introduction of something new (or renewed, a novel change) which turns into an economic, social or environmental benefit for rural practice."

European Commission [67]: "Social innovation means developing new ideas, services and models to better address social issues. It invites input from public and private actors, including civil society, to improve social services."

Innovation Policy

The European Parliament discusses the EU's innovation policy as cross-cutting, helping to address other EU policies, such as those concerned with competitiveness, industry, environment, and energy. It claims that "the role of innovation is to turn research results into new and better services and products in order to remain competitive in the global marketplace and improve the quality of life of Europe's citizens" [65]. A key motivation for introducing this policy is to counter brain drain. Comparisons to the USA and China are made to justify the promotion of innovation policies. The European Parliament therefore created the "Innovation Union"; the Horizon 2020 research framework; a cohesion policy which ring-fences $80 \%$ of the resources from the European Regional Development Fund in more developed regions for innovation, namely, in the areas of low-carbon economies and competitive small and medium enterprises (SMEs); financial instruments supporting innovation, such as "InnovFin-EU Finance for Innovators"; and an Innovation Council (see below) [65]. 
The Innovation Principle

According to the European Innovation Factsheet on the innovation principle, the latter is stated as, "EU policy and legislation should be developed, implemented and assessed in view of encouraging innovations that help realise the EU's environmental, social and economic objectives, and to anticipate and harness future technological advances." The rationale behind this principle includes the idea that it is necessary to create regulations that facilitate and are flexible enough to allow innovation, as there is a tension between regulation and the unpredictable nature of innovation. For this reason, the innovation principle proposes that a balance between regulation and flexibility should be applied throughout the entire policy-making process, from agenda setting to implementation [68,69].

This principle was originally proposed and pushed in 2013 by major companies making heavy investments in innovations in the EU, such as Bayer, Dow, IBM, and Phillips. These argued that there was too much emphasis on the precautionary principle in the EU, and that this was stifling innovation [70-72]. This origin was, until recently, not mentioned in most formal EU documents on the subject [72], and in fact the innovation principle itself is not widely known [23].

The innovation principle has been seen by some as contrary to the precautionary principle. The Corporate Europe Observatory [71], for example, wrote that "The creation of the 'innovation principle' opens up new opportunities for corporations to use the impact assessment phase, which precedes the drafting of new or revised rules, to their advantage by claiming harm to innovation. Such a claim is easy to make when 'innovation' is not defined." The key focus of the innovation principle on growth and job creation is in line with key goals of the EU, but in contrast to other "principles," it does not include rules on safeguarding consumers and environmental needs [23,71].

The Innovation Union

The European Parliament [65] describes the Innovation Union as "one of the seven flagship initiatives of the Europe 2020 strategy for a smart, sustainable and inclusive economy. Launched by the European Commission in October 2010, it aims to improve conditions and access to finance for research and innovation in Europe so that innovative ideas can be turned into products and services that create growth and jobs. The Innovation Union aims to create a genuine single European market for innovation, which would attract innovative companies and businesses. To achieve this, various measures have been proposed in the fields of patent protection, standardisation, public procurement and smart regulation. The Innovation Union also aims to stimulate private sector investment and proposes, among other things, to increase European venture capital investments." The Innovation Union is one of the key results of the EU's Innovation Policy described above, and is meant to facilitate its implementation.

\subsubsection{Entities}

The European Innovation Council (EIC)

The EIC is described in the EC's factsheet as contributing chiefly to the EU's key goals of "A European Green Deal," "An economy that works for people," and "A Europe fit for the digital age" [73], thus aligning itself well with the objectives of sustainability, economic growth, and social inclusion, as well as highlighting the need for digital innovation to achieve them. The EIC is described as follows:

"Europe needs to capitalise on its science, innovative SMEs and start-ups to compete in global markets increasingly defined by new technologies. That is why the European Commission has introduced a European Innovation Council (EIC) to support high-risk, high-impact ideas, turning science into new business and accelerating the scale-up of 'game-changing' innovators shaping the future. Currently in its pilot phase, the European Innovation Council will be fully implemented from 2021 under Horizon Europe. It will support our global competitiveness by helping our best innovators develop and scale their ground-breaking ideas. [ . . . ] The goal of the European Innovation Council is to put Europe on top of the next wave of breakthrough and disruptive innovation 
that creates new markets, in particular by combining physical and digital products and services based on new technologies business models. It aims to make Europe an internationally attractive place to develop, invest and scale up highly innovative technologies and companies." [73]

European Innovation Partnerships (EIPs)

European Innovation Partnerships were introduced in 2010 by the European Commission as an entity to "overcome fragmentation of efforts and slow pace of change in the establishment of Innovation Union," noting that "EIPs do not supersede or replace other existing initiatives and platforms, nor are they a substitute for existing institutional decision-making mechanisms. They mainly reinforce the coherence of European research and innovation priorities and accelerate the uptake of innovations" [74]. The European Commission further specifies that "the activities of EIPs spread out the whole research and innovation chain and aims at bringing together all relevant stakeholders at both scales, national and regional. The main goal of the Partnerships is to design and implement innovation-based activities to cut lead times, with particular emphasis on;

1. stepping up research and development efforts;

2. coordinating investments in demonstration and pilots;

3. anticipating and fast-tracking any necessary regulation and standards;

4. mobilising 'demand' in particular through better coordinated public procurement to ensure that any breakthroughs are quickly brought to market.

The important characteristic that makes EIPs different is the attempt to coordinate existing instruments and initiatives and complement them with new actions where necessary. In other words, the EIPs can be seen as an integration tool to develop a single coherent policy framework by means of helping the existing initiatives to achieve better and faster results" [74].

One of the EIPs has specific relevant consequences for the future of urban planning practice and research, as also noted by the European Commission [74]: "EIP on Smart Cities and Communities (EIP-SCC): works to improve urban life through more sustainable integrated solutions, including applied innovation, better planning, a more participatory approach, higher energy efficiency, better transport solutions, intelligent use of information and communication technologies (ICT), etc."

Innovation Communities

Innovation Communities are a part of the European Institute of Innovation and Technology (EIT) and are described as partnerships between research centres, businesses, and universities, with at least three objectives:

- "innovative products and services to be developed in every area imaginable, including climate change, healthy living and active ageing

- $\quad$ new companies to be started

- a new generation of entrepreneurs to be trained" [75].

It is furthermore interesting to note that the EIT, which creates and helps to fund the Innovation Communities, specifically aims at integrating the "fragmented European innovation landscape" to enable its "pioneering role in increasing European sustainable growth and creating jobs by reinforcing Europe's innovation capacity" [76]. This is well linked with the notion of "directionality" of innovation, to be explained in relation to "Missions" below.

\subsubsection{Operationalizations}

Innovation Deals

Innovation Deals are "voluntary cooperation agreements between the EU, innovators and regional or local authorities. They evaluate specific EU rules or regulations to see if they are a barrier to innovation" [3]. The Deals aim to facilitate collaboration on the innovation objective on all levels of governance (i.e., from the creation of EU policies to 
local government implementation) and to create understanding about the EU innovation policies that can enable the removal of barriers to innovation [3]. The Deals are not funded. There are two signed Deals, both related to the circular economy (electric vehicles and recycling, and wastewater treatment).

\section{Innovation Procurement Guidance}

The latest Guidance on Innovation Procurement from the EU was published in 2018 and aims to advise in a non-binding way on how Member States can choose products and services to aid in their governance and economic development [77-79]. The announcement of the publishing of the 2018 guidance cites the Commissioner for the Internal Market, Industry, Entrepreneurship and SMEs, saying that "Public authorities in the EU spend nearly $14 \%$ of GDP purchasing services and products. If spent strategically on innovative solutions, public procurement can contribute to higher quality and sustainable public service and lead to economic and social benefits. It creates demand for new ideas and innovative start-ups to emerge and grow. We are here to assist the Member States that choose to do so" [78].

\section{Innovation Scoreboards}

The European Commission defines its own innovation scoreboard as follows: "The European innovation scoreboard provides a comparative analysis of innovation performance in EU countries, other European countries, and regional neighbours. It assesses relative strengths and weaknesses of national innovation systems and helps countries identify areas they need to address" [80]. The document presenting the 2020 scoreboard cites Commission President Ursula von der Leyen noting that "We must turn the immense challenge we are facing into an opportunity by investing in our common future with the help of the recovery plan. The European Green Deal and our digitisation initiatives will boost jobs and innovative growth, the resilience of our societies and the health of our environment. This is Europe's moment" [81]. It is noteworthy that, through the scoreboard, innovation became a quantified asset. As stated here: "The 2020 edition of the innovation scoreboard highlights that the EU's innovation performance continues to increase at a steady pace, with growing convergence between EU countries. On average, the innovation performance of the EU has increased by 8.9\% since 2012" [80].

Innovation-Friendly Regulatory Framework

The "Better Regulation" Guidelines were introduced in the EU in 2015 and they "set out the principles that the European Commission follows when preparing new initiatives and proposals and when managing and evaluating existing legislation. The guidelines apply to each phase of the law-making cycle" [82]. They aim to make EU regulation more accessible and transparent [23]. Within the better regulation guideline's general framework, innovation is considered usually in relation to competitiveness, and is a compulsory "specific impact classification" for regulations [5]. As Garnett et al. [23] emphasize, the better regulation guidelines are well regarded by businesses and industry, who see themselves relieved of regulatory burdens. The better regulation guidelines also led to the development and integration of the innovation principle (see above), further justified within the "better regulation" logic as follows:

"The Commission Better Regulation procedures and its rolling REFIT programme provide a framework for this work, allowing it to enhance innovation-based opportunities for sustainable growth, jobs and competitiveness. A favourable regulatory framework would also enhance the impact of Horizon 2020 financing instruments, which support initiatives to tackle societal challenges and ensure industrial development, innovation and competitiveness in Europe."

Growth and job creation are top priorities of the Juncker Commission. Better Regulation, which helps unleash the full innovative potential of our firms and people, is central to the growth and jobs agenda. As President Juncker said: 
'Jobs, growth and investment will only return to Europe if we create the right regulatory environment and promote a climate of entrepreneurship and job creation. We must not stifle innovation and competitiveness with too prescriptive and too detailed regulations [...] "red tape" both at European and at national level that could be swiftly removed as part of my Jobs, Growth and Investment Package'" [7]

Tool \#21. Research and Innovation

The "Better Regulations" Guidelines described above include a "Better Regulation Toolbox" [83], within which Tool 21 is dedicated to research and innovation. This tool is described as follows: "This research and innovation Tool provides clear guidelines for analyzing the interaction between new or revised EU legislation (including spending programmes) and innovation. In addition, it outlines a series of design considerations and operational instruments that can be used to make legislative proposals more forwardlooking and innovation-friendly. The Tool is not limited to looking at impacts on technological innovation but can also be used to look at other forms of innovation such as social, business model and public sector. Other tools in the Toolbox can also be used to identify and assess impacts flowing from innovation" [84].

The Innovation Radar

Innovations supported by the EU are indexed, classified, and ranked through the "Innovation Radar" of the European Commission. It is described as "the European Commission's data-driven method focused on the identification of high potential innovations and the key innovators behind them in EU-funded Research and Innovation projects. [ ... ] The data gathered by this method is used to categorise EU-funded innovations in terms of market maturity and disruptive potential [ ... ]. It supports innovators by suggesting a range of targeted actions to assist them in fulfilling their potential in the market. It not only gathers data sets about innovative potential but also ensures that, during their project lifespan, EU-funded researchers and innovators get expert advice about the most appropriate steps to reach the market with their innovation" [85].

Missions

In 2018, the European Commission introduced the concept of "Missions" into its innovation lexicon through the report "Mission-Oriented Research \& Innovation in the European Union: A problem-solving approach to fuel innovation-led growth" by Mariana Mazzucato. This report argues that innovation must not only be strongly promoted, but also strongly guided. This is put in the following way [2]:

"The ability of innovation to spur economic growth has long been recognised. Less recognised is the fact that innovation has not only a rate but also a direction. By harnessing the directionality of innovation, we also harness the power of research and innovation to achieve wider social and policy aims as well as economic goals. Therefore, we can have innovation-led growth that is also more sustainable and equitable. Finding ways to steer economic growth, and the European policy agenda, is difficult but necessary. Missions are a powerful tool to do this. They can provide the means to focus our research, innovation and investments on solving critical problems, while also spurring growth, jobs and resulting in positive spillovers across many sectors."

Missions are of critical importance for the current logic of European funding. The EU states in one of their webpages that [86]

"Partly inspired by the Apollo 11 mission to put a man on the moon, European research and innovation missions aim to deliver solutions to some of the greatest challenges facing our world. They are an integral part of the Horizon Europe framework programme beginning in 2021. Each mission is a mandate to solve a pressing challenge in society within a certain timeframe and budget." 
The on-going missions are: "Conquering Cancer: Mission Possible," "A Climate Resilient Europe-Prepare Europe for climate disruptions and accelerate the transformation to a climate resilient and just Europe by 2030," "Mission Starfish 2030: Restore our Ocean and Waters," "Caring for Soil is Caring for Life," and "100 Climate-Neutral Cities by 2030_by and for the citizens." This last mission, as the name points out, has very clear implications for urban planning.

As the Chair of the Mission Board for Climate Neutral and Smart Cities notes [87],

"The introduction of a Climate City Mission is a radical new way of achieving climate neutrality - and of doing so faster, by 2030. The Mission aims to promote system innovation across the value chain of city investment, targeting multiple sectors such as governance, transport, energy, construction and recycling, with support from powerful digital technologies. As such, it requires a change in regulations, approaches and instruments combined with the willingness to go beyond existing schemes and habits."

\subsubsection{Discussion of the Lexicon}

A strong relationship between innovation and the values of sustainability and economic growth, as well as "social benefits," is assumed throughout the terms introduced in this lexicon. Economic growth (but, to a large extent, also social well-being) is mainly understood in terms of job creation and competition and is central to the notion of innovation as understood in the EU. Although mention is made of social and other "types" of innovation, technological innovation dominates. The implicit assumption seems to be that social inclusion and sustainability will be by-products of economic growth, or that at least through innovation the tension between these objectives will be solved-an assumption that is common in growth-oriented thinking but is being increasingly challenged [44-46,88].

The lexicon of the European Union concerning innovation is supported by a simple and rather repetitive set of justifications. These justifications essentially shuffle and recombine words such as "innovation," "innovative," and "innovation-friendly" with "economic growth," "fast," "acceleration," "new markets," "job creation," "companies/firms/business/industry," "competitiveness," "disruption," and "breakthroughs." The patent assumption informing EU innovation-related documents is that all of these concepts have positive and virtuous synergies among themselves, creating benefits for all involved, and therefore all should be abundantly promoted and used in the maximum amount of policy documents possible. The result is a repetitive and predictable reading, and one where the potential drawbacks of the choices made are not discussed. On the contrary, an effort is made to present the concepts in an appealing and motivational way. With the emergence of the notion of Missions, this became even more noticeable, and statements such as "THIS IS THE MISSION OF OUR TIMES!" ([87] capital letters in original) or "This is Europe's moment" [81] increasingly appear. It should be noted that the abundant repetition of such a limited set of ideas should not be underestimated as a policy measure in itself, as it creates an important path dependency [71]. As, for example, Lorne [54] shows, the notion of Missions and related policies is neoliberal and aligned with the promotion of economic growth, while maintaining a chiefly monetary relation to sustainability (it is only promoted if it can be made profitable) and perpetuating social exclusion. Note that positive academic reflections on directionality and Missions in policy making in relation to innovation also exist (see, for example, Diercks et al. [32]), though they do not reflect critically on the notion of innovation policy.

\subsection{Urban Planning Innovations Supported by the EU}

The analysis of twenty-one projects funded and supported by the EU based on their innovation potential is presented in summarized form in Appendix B. Without criticizing the projects, it is possible to recognize that the innovation policy of the EU leads to initiatives that have a very specific scope. They tend to emphasize social inclusion and/or sustainability, often framed in relation to economic growth. However, in their specifics, it is clear that they envision to address these topics through efficiency, digitalization, including 
the production and use of "big data," emphasis on "smart" technologies, and the use of behavioural change arguments (i.e., individuals need to change their behaviour and, as a result, growth, sustainability, and inclusion goals will be met). For example, MOBINCITY develops a full ICT system for "smart" technologies to improve energy efficiency; PORTIS aims to induce more sustainable mobility behaviour (e.g., modal shift) through multimodal hubs; PULSE aims to address health issues through digitalization and big data collection; and so on (see Appendix B for details on all projects and a specification of which themes were identified in each project.). Within twenty-one projects, only three slight exceptions could be found that do not confirm exactly this focus-however, they do not provide radically different ideas. MAKING-CITY, RISEN, and CIVITAS ECCENTRIC are all less focused on efficiency, digitalization, including the production and use of "big data," emphasis on "smart" technologies, and the use of behavioural change arguments than the other projects, but do have several of these characteristics, and their tone and objectives fall well within the narrow perspective on innovation discussed in this article. MiRTLE discusses a radically different subject, terrorism, but it, like the others, focuses on offering a technology to solve the problem, and aligns with the objective of economic growth, and so is again also aligned with the narrow view on innovation described.

Overall, the outcomes of European innovation policy applied to urban planning thus present a serious lack in diversity and, indeed, of "innovation" in terms of proposing alternative ways of addressing identified problems, or of identifying them in the first place. This might be explained by the explicit calls for "innovative" projects by the European Union, or the selection criteria applied within the innovation agenda or specific calls based on it, which ask for precisely these frames of reference. Another example is the 2017 Horizon 2020 call for social innovations to aid the mobility of the elderly. All three key awarded projects here involved a type of technology or gadget and nearly all ten finalists do as well $[89,90]$.

The project descriptions present yet another commonality. Many of the projects, especially newer ones, explicitly write about "proving" or "demonstrating" a particular positive result to be expected from a given innovation proposed by the project itself (see emphasis in bold in Appendix B). Only older projects present narratives concerned with testing hypotheses and try to demonstrate some level of scientific rigour and critical detachment from project results. Critically analysing the benefits or added value of innovations vis-à-vis their costs or risks is not proposed, or at least appears not to be rewarded by EU funding. This mirrors the increasing tendency of EU policies to also have a mobilizing and sales-pitch style, as shown in the lexicon as well. Through this—and as will be explored further in the next section-innovation policy has the potential to create significant disadvantages and obstacles on the ground.

\subsection{Two Local-Level Urban Planning Illustrations: Local-Level Drawbacks of Planning Based on EU Innovation Policies}

This section separately discusses two different illustrations. First, the illustrations are briefly described, highlighting their struggles with the concept of innovation, and then critically analysed. Finally, some of the drawbacks of innovation policy applied to local-level planning are proposed.

\subsubsection{Mobility for the Elderly in the Netherlands}

In 2016, a community-based initiative for local mobility for the elderly was begun in the Netherlands, motivated by serious detrimental effects on health and well-being found among elderly people experiencing isolation in neighbourhood X. Part of the solution was seen in facilitating the mobility of these elderly people through a local small-scale electric vehicle that could be ridden as a minor and inexpensive type of "taxi" service for the elderly within a small radius, but allowing them to reach local services such as grocery shops, hairdressers, flower shops, the local health institute's restaurant, and so on (see details on how the initiative was studied in Section 3 above). The initiative was supported by the local community centre, the local health institute, a regional lease company for the proposed 
vehicles, and a regional sustainability NGO. This initiative looked for funding through a variety of sources, pitching their initiative as socially innovative to highlight their added value. Several of the initiators felt a certain pride in presenting themselves as delivering an original idea for the rescue of a vulnerable group in their own neighbourhood. They also recognized that innovation funds abounded and felt that this would be the best bet for their hopes for governmental support. They pitched their idea to two local government officials, both of which reacted positively. However, when these officials found out that they had both been approached simultaneously, and both had planned to pitch the project at the local assembly, their rivalry on the ownership of the project resulted in their agreement that neither of them would support the project. Eventually, in 2017, one of the local officials decided to support another initiative based on a very similar idea, but in a different place: neighbourhood $Y$. When, shortly thereafter, the initiative of neighbourhood $X$ applied for funding based on their innovative character, they were disqualified because they were not innovative enough. The project was assessed in this way because a similar project already existed, in neighbourhood Y. Disappointed, the initiative members nearly gave up on their initiative, but continued revising their approach over several years, and eventually were able to secure sufficient non-governmental support to be able to start the initiative in 2019 .

This illustration highlights how projects that choose to pitch themselves as (socially) innovative with the purpose of securing funding-as the EU and local governments encourage them to do-set themselves up for a vulnerable position and a number of pitfalls. They become particularly vulnerable to political will, because the assessment of whether a project is considered innovative is very dependent on interpretation and what elements of an initiative are highlighted. For example, in the case presented here, the use of small electric vehicles and their reach and target group were the same in the two initiatives, but their organizational structure could be looked at as different, as one focused more on employing volunteers, while the other focused on employing professionals to ride the vehicles. A small difference, but one a politician seeking to give support could choose to emphasize-or not.

Support based on innovation also entails accumulating significant prestige for the initiatives, as well as politicians endorsing them, which can create competition, to the detriment of achieving improvements in various rather than just one neighbourhood or location. Furthermore, such an initiative will be seeking ways in which it can convince others of its innovative character, rather than focusing on effectively promoting public goals such as societal well-being and health.

A public official interviewed on the subject agreed that initiatives that do have value for their neighbourhood are sometimes not funded because they are not deemed innovative, while innovation funds constitute a large and increasing share of the few funding opportunities for initiatives. This public official also noted another issue that emerges due to the innovation policies to be implemented at the local level:

"We have started some innovation ateliers. That sometimes delivers really nice projects. Something that we are confronted with there, though, for example, is that you get selfemployed people that are simply looking for a project. Do you then find that ok? Or do you say, yes, well, we precisely want to stimulate local inhabitants that simply have a good idea for their neighbourhood and who aren't really in it for the money? We've had quite a few discussions about that."(Interview local official, 2018, author translation from Dutch)

The public official clearly struggles with whether the innovation policy should leave room for funding people that are only or chiefly "in it for the money," as she argues selfemployed applicants usually are, or whether it is legitimate to allow only initiatives that are proposed by "local inhabitants." The paradoxical aspect of this view is that it assumes that local inhabitants cannot be self-employed if they are to be perceived as local inhabitants, and that they should not show an interest in money, although this might be needed for their subsistence. The official struggles with how to interpret innovation policy-should it be about who proposes it, or about the effect on the ground, or about who gets what 
share of money, or should it be about money at all, and so on. A discussion on this at a political and participatory level does not seem to be possible or desirable. This also shows that it can have problematic effects to make innovation into an all-encompassing concept, which can be broadly interpreted and leaves local officials struggling with-and in some cases taking advantage of-defining priorities on the spot. This openness can be seen as beneficial in terms of being able to adapt to local needs, but at the same time, it removes the setting of such priorities from public deliberation.

In summary, this illustration highlights three key drawbacks of innovation policy for local urban planning:

- $\quad$ initiatives being encouraged to focus on displaying signs of innovativeness, rather than seeking to demonstrate their added value in more concrete terms relevant to their context;

- $\quad$ initiatives being vulnerable to wilful interpretations of policy makers and funders, who can decide to focus on the elements that do, or those that do not, highlight their level of innovation- something that is easy to do because of the vagueness of the innovation concept;

- the open interpretability of what can be funded on the basis of innovativeness leaves local government struggling to set ad hoc priorities that are not co-determined democratically, which can be seen as difficult for some, and as an (undemocratic) opportunity to push for personal agendas for others.

\subsubsection{A "Repair Café" in Leipzig, Germany}

In his article critically reviewing social innovation policies and their effects, Timmo Krüger [16] describes an initiative from Leipzig, Germany, called "Café Kaputt." This is a local initiative founded in 2012 aiming to facilitate people coming into the café to learn how to repair everyday objects brought in by themselves. The café is entirely run by members that work based on charity funds given by users. The café also encourages discussions on alternative economies, recycling, and similar themes. As Krüger [16] describes, the initiative first benefitted from funding associated with the regional innovation policies in place, since the idea of such places had not yet emerged in Germany and could, therefore, be presented as innovative in this new context. However, over time, the "pressure to innovate" became increasingly problematic, as the project wanted to focus on maintenance of the idea due to its public interest, rather than on ways it might further change the idea. Funding could, however, only be secured for "innovative" additions to the café, and not for maintenance costs (e.g., to pay for the rent of the location, or for management or tools).

Krüger [16] highlights a set of drawbacks of social innovation policies for which he employs this example: conflicts and power questions are left unaddressed and distracted from; incremental political action is prioritized over transformative types; and ignorance about traditional contextual forms of life abounds. He also notes that the "innovation imperative," as he calls it, "decreases the possibility to plan ahead and maintain wellproven offers" ([16], author translation from German).

In this article, we would like to point out additionally that this case demonstrates the damaging effect of innovation policy as—similarly to the Dutch illustration above-it forces initiatives to focus on presenting themselves as innovative instead of on actually contributing to their neighbourhood in more significant qualitative terms. It also shows that insisting on praising the innovative leads to the paradox of initiatives having to present themselves as innovative when that is not at all logically coherent; indeed, repairing household items used to be a perfectly established practice (until it was deemed historical due to the emergence of technological innovation focused on creative destruction). It is strange to consider something as innovative which our grandparents used to do; nevertheless, it was on such grounds that the Café Kaputt won its innovation funding. Furthermore, it shows the lack of support for maintenance initiatives (and for the sustainable maintenance of household items), as is already tangentially mentioned by Krüger (but see also, for example, $[19,91])$. 


\section{Discussion}

The above findings suggest that current innovation policy (whether classified as technological, social, or another type) provides a narrowing, rather than horizon broadening, perspective for policy. The findings also leave questionable the extent to which, due to current innovation policy, the interests of the wider public or of the environment are sufficiently prioritized over the (often vested) interest of powerful actors. In this discussion, these findings are related to a number of existing criticisms of innovation policy, and suggestions for dealing with the apparent drawbacks are made. The discussion is organized in three parts: the first is concerned with understanding and suggestions about the future, the second about the present, and the third about the past.

\subsection{Thinking about the Future: From Innovation as a Narrowing Policy Device to Real Policy Diversity}

We have seen above how the implicit conceptualization of the future in EU innovation policy is one characterized by directionality. In practice, this means that it is considered legitimate and necessary to promote a very specific policy logic, in this case characterized by innovation in general and by innovation based on efficiency, digitalization, smart technologies, and behavioural change for the achievement of economic growth in particular. The future should essentially be shaped by these concepts. Social inclusion or equity and environmental sustainability are mentioned, too, albeit less frequently, as they are seen as by-products of economic growth. There is ample literature, however, presenting arguments against efficiency [92-94], digitalization and smart technologies [53,95,96], behavioural change $[97,98]$, and economic growth $[44-46,88]$ - particularly when the objectives are sustainability and social inclusion. The investment in these policy funnelling processes is, therefore, a reason for concern.

This article proposes an approach to move beyond this funnelling process, comprising three steps. First, acknowledging the limitations of adopting a narrow view of innovation, and therefore reinvigorating the concept's openness to more radically different thinking and action (see, e.g., [99] on the risk of "program monocultures" for adaptive capacity).

Second, acknowledging that focusing policy on innovation dismisses the value of historical or established policies, which could constructively inform valuable solutions for urban planning and beyond ([19], see, e.g., [24,91]). Consider, as examples of historical approaches that could (and are being) considered today, the case of cycling in urban areas before car use became mainstream; or consider the use of vacant pieces of land for urban agriculture. It is not because such practices lack innovativeness that they are more or less relevant for the public interest-though they frequently make attempts to present themselves as innovative and to collaborate with innovation industries to heighten their opportunities for funding (on cycling see, e.g., [100-103], and on urban agriculture/local food growing, see [33]).

To illustrate the argument, Figure 1 depicts the space of policy alternatives. It takes the form of a triangle, each angle representing extreme alternatives that a policy might focus on: the innovative, the established, or the historical. The tips of the angles are cut off by a limit line, since a pure version of "innovation," "historical," or "established" as depicted by initiatives A, B, and C cannot exist-an important realization to make. A somewhat larger space in the vicinity of the angles is fenced off to indicate the ways in which policies and political choices limit possibilities as they focus on one of the three concepts. These limits can be called binding policy paradigms, of which the innovation paradigm is one, but each of the other angles can provide its own. Initiatives D, E, and F are therefore possible initiatives, but planning and policy that focuses on one of them discards the potential value of the other two. Initiative G, finally, is positioned randomly in the centre section of the triangle to illustrate such initiatives that might be supported by policies that are not bound by policy paradigms focusing on one particular corner of the triangle. Note that in the latter case, initiatives D, E, or F may also be supported, but do not receive any special attention as compared to any of the others. 


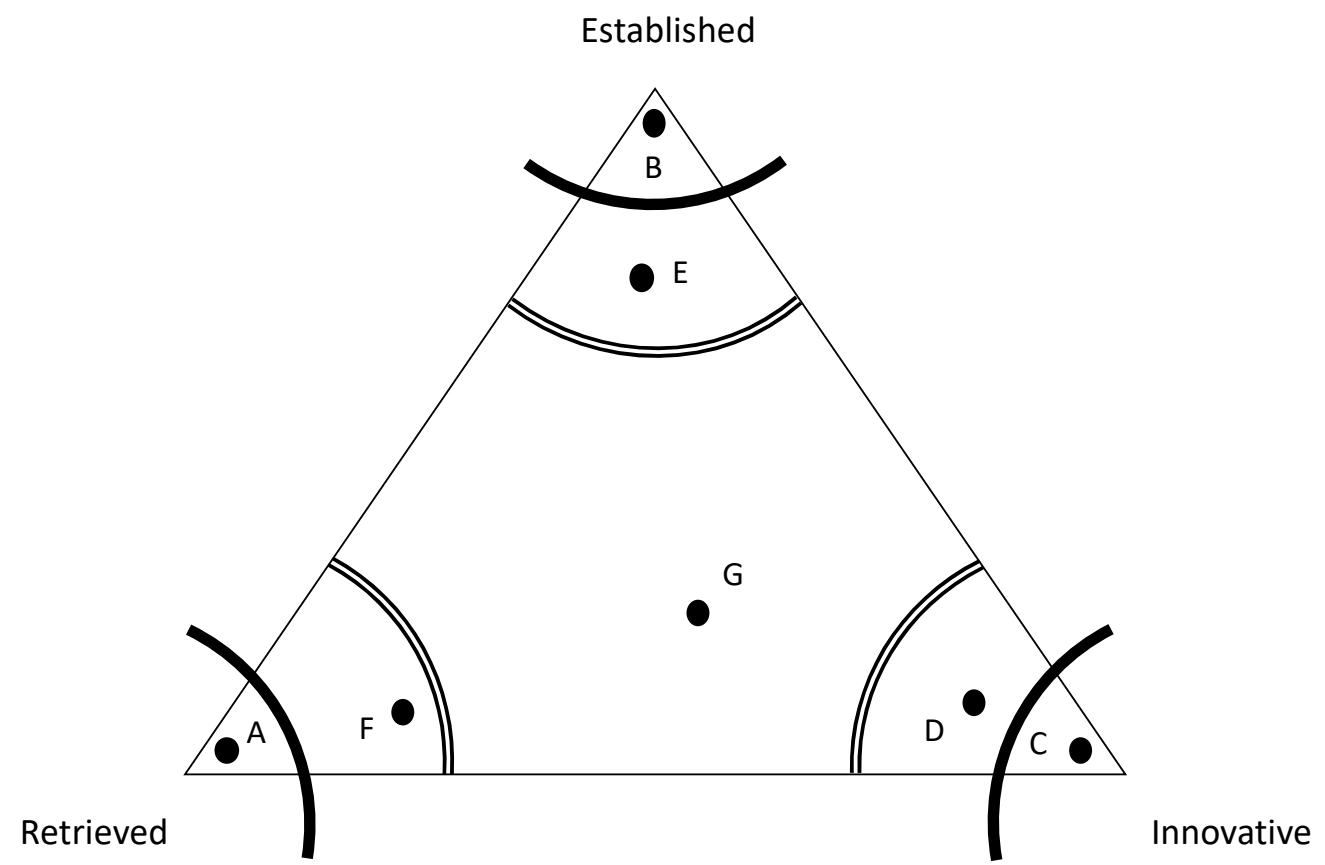

Figure 1. The space of possibilities for policy making in terms of novelty (source: authors).

The focus on innovation as a binding policy paradigm is very similar to conservative policies that focus entirely on maintaining the status quo, or policy paradigms that herald the past as the ideal into which the present should be moulded. Through the creation of such limiting logics, all possibilities offered in the space of policy alternatives beyond the adopted binding policy paradigm are likely to be discarded. Removing these binding paradigmatic lines constitutes the second step of the proposed approach to move beyond the funnelling process of innovation policy - thereby acknowledging the value of using the entire space of possibilities for policy alternatives and the fact that insisting that initiatives must follow the dictums of any binding policy paradigm involves a needless and potentially damaging narrowing of the space of possibilities for policy. Indeed, the most suitable policy might clearly lie outside the adopted binding policy paradigm and be discarded or, more likely, not even be considered due to the dominance of such a paradigm (for further insights, see [26]).

Third, and finally, what the triangle in Figure 1 should demonstrate most is that making policy based on binding policy paradigms distracts policy makers and implementers from serving the public interest (i.e., focusing on goals such as sustainability or social justice). Innovation cannot be considered a proxy for the public interest because it constitutes only a possible means to achieve it, and one that might lead to policy failure-in the same manner that retrieving historical policies or fixating on the status quo are only means to achieve the public interest, which themselves might also fail to deliver. Indeed, and as an example, a potential paradox permeates the EU's dominant narrative of innovation as a means of promoting jobs and economic growth, in relation to its focus on digitalization and automation. Simply put, the economic literature on job displacement proposes that, on one hand, process innovation tends to initially lead to labour savings, as it represents a decreased need for human input. However, the level of job displacement induced by process innovation is argued to be eventually outmatched by new job creation induced by higher process productivity. This is said to result in lower product selling prices, higher consumption, and therefore higher overall economic activity that ultimately boosts job creation. On the other hand, it is argued, product innovation tends to directly generate new jobs as it leads to higher levels of productivity, lower product costs, and therefore to higher consumption - thus also contributing to boosting economic activity on which job creation depends. This line of argumentation, however, can downplay the risks of 
innovation-oriented policies in terms of de-skilling, unemployment, and the degradation of labour conditions for all except those in high-level positions and work in sectors dedicated to high-tech manufacturing [104-108]. It can also lead to soaring environmental impacts derived from an economic system that makes economic growth and job creation dependent on ever-increasing consumption in a world of finite resources $[46,88,109]$. In other words, innovation (especially as promoted by the currently dominant narrative) can be potentially associated with the increasing levels of social inequality, labour injustice, and environmental degradation we witness today. That which might constitute one of the sources of key contemporary global problems thus appears to be uncritically presented as the primary solution for them.

Instead of focusing on any one of the angles of the space of policy alternatives, or even on where in the entire triangle a policy might be placed, policy making at any level of governance could benefit from primarily engaging with the societal purpose of their policies and the ways in which they address the public interest. In doing so, conceptions of past, present, and future can all be used to inform policies without the excessive interference of unwarranted binding policy paradigms. The next two sub-sections explore some reasons why thinking about and including the present and the past in policy making can be crucial, namely, for identifying truly diverse solutions so that societal and environmental problems can be effectively addressed.

\subsection{Thinking about the Present: From Broad Terminologies and Social Acceleration to Resonant Engagement}

As both the innovation lexicon and projects in the EU presented above show, a clearly identifiable style of writing dominates, and its key characteristics are simplicity, recognizable terminologies, and the use of sales-pitch language. This aligns itself well with a logic of social acceleration [50,110-112] where the perceived extension of the present moment becomes increasingly small, and where individuals accumulate an increasingly harder to manage temporal deficit. This translates into an enormous sense of rushing and pressure. Policy documents have to become, as a result, increasingly predictable and easier and faster to read. They also have to become increasingly appealing and comparable to sales pitches, otherwise their readers will soon disengage and move on to other topics. Understanding these issues requires further explanation of the concept of social acceleration.

Social acceleration can be understood as a process where essentially everything (from technologies to social practices to institutions) changes increasingly faster, forcing democratic institutions to work at an exceptionally (and ever increasing) fast rhythm that is incompatible with democratic forms of decision making and public deliberation, as these are by default rather slow. As a result, these institutions tend to outsource and privatize a growing number of decision-making processes. This represents a problem for democracy, as it empowers for-profit private organizations, which in turn require innovation to remain competitive in the market ([23], see, e.g., [71,72]). Aggravating the situation, and through innovation, these organizations become sources of new polemical issues that require further democratic decisions and public deliberations. This is a self-reinforcing process. When this process is undertaken at the European level, where a growing number of decisions is supposed to be taken (see the impressive list of 291 policies endorsed by the EU [56]) in an environment also characterized by tremendous dissimilarities among Member States, an enormous political complexity and wariness accumulates.

To a large extent, the envisioned solution for this untenable situation emerges in the form of "boundary" terminologies, of which innovation has become one [113]. Such boundary terminologies are based on leaving concepts deliberately broad or vague so that they can be accepted at high levels of European governance and then interpreted as seen fit at local levels, while also leaving them open to creative interpretation as new problematics inevitably emerge due to socially accelerated dynamics. Such terminology appears to simplify governance due to this flexibility. However, we have seen in the empirical material above that, at least in the case of the term innovation, such treatment 
rather results in the enabling of a particularly divisive and socially accelerating political agenda (e.g., digitalization and smart technologies, preferably provided or supported by large-scale industries), and in giving a level of discretion for decision making at the local level that easily leads to controversial dynamics. It is therefore questionable whether such deliberately broad terminologies can be beneficial for the public interest (in fact, discussions of what the public interest entails have been side-lined in planning and beyond for years [51]), and whether solving the problems of social acceleration through innovationbased solutions that further accelerate the pace of change is a wise choice.

Social acceleration refers to a general push for more dominating in all areas of lifemore money, gadgets, books, experiences, all made possible through more work, shopping, travel, growth. The currently dominant conception of "the good life" [114] is so based on these ideas of more-and faster so that more can fit in the limited time available - that contemplated quality, in-depth learning, and concepts such as degrowth become almost unthinkable. Importantly, and as Rosa $[115,116]$ also notes, long-winded social acceleration in the search for more is leading not to increasing abundance and prosperity, but to a painfully rushed state of affairs where individuals instead do increasingly more to simply maintain what they already have. This is well patent in the policy narratives of the EU, where the search for competitiveness through innovation aims to simply maintain Europe as a competitive global player against powerful forces such as the USA or China. At an internal level, this was also well patent in previous "austerity" policies, where the Member States running behind in the competitive race were essentially forced to catch up at all costs. Democratic deliberation and public mobilization against such dynamics were considered a lack of discipline to be severely punished [117].

Social acceleration induced by innovation is related to the narrowing of policy described above; narrowing possibilities appear to make decisions less time-consuming and therefore faster, as there is no time to waste due to the competitive game. However, it becomes necessary to "sell" these ideas with flashy terminologies that make them convincing to the rushed minds of readers, and to anyone that feels less inclined to agree with their hegemonic qualities.

Social acceleration also leads to the focus on project-based research and policy. Projects are set up to confirm their hypotheses as efficiently as possible in as little time as possible. There is no time for exploration and testing ideas for their value and validity along critically analysed and democratically discussed policies. Projects are needed because they can be given specific allocations of funding and time within which they deliver continuous and continuously predictable results. Critical thinking becomes side-lined, or mainstreamed far enough to become set in line with the already given policies and language. As this occurs, endorsed initiatives and policies are in danger of missing objectives, such as sustainability or social inclusion, so that the "means," such as innovation and economic growth, can be prioritized. At the same time, these initiatives and policies and the research meant to "prove" their worth become increasingly predictable, perhaps even biased. This has a strong potential to encroach on learning capabilities at a societal level, as will be discussed in the next sub-section.

The conclusion to be drawn is that there is a strong need to challenge the double imperative of increasing competitiveness as an answer to increasing competition, and of increasing social acceleration as an answer to social acceleration itself. Instead, it seems important that contemporary societies develop "reflexive breaks" that allow them to critically analyse the choices they are making and have been making [49] and "resonant engagement" that allows them to see personal relations with other humans and with the world reflectively and without the expectation of immediate and continuous gratification $[50,112]$.

\subsection{Thinking about the Past: From Willed Amnesia to Historical Awareness}

If with the current logic of innovation policy, the present has become dominated by vague conceptualizations and social acceleration, the past has been increasingly neglected. This is reflected in, first, initiatives with relevance for the public interest seeing their 
funding cut as soon as they stop being assessed as innovative, which inevitably happens the moment after they are implemented and become part of the forgotten past [16,91].

Second, this is reflected in the rare occasions when innovation-oriented European policies and projects are critically assessed, because once something is implemented, it becomes part of the checked-off past and attention should then move on to the next innovation. An exception to this is the "Study supporting the interim evaluation of the innovation principle" [61]. Even here, however, a close reading reveals that the innovation principle was to a large extent assessed in terms of its capacity to promote an innovationfriendly policy environment. This is a circular form of assessment where means are equated with ends, and where innovation is conflated with the public interest-a common trait of innovation-centric policy making [26].

Third, and partially due to the above, this is reflected in the consistent and cumulative learning deficits that can emerge from an excessive focus on innovation $[18,118]$. These learning deficits result from the lack of time and dedication devoted to assessing and understanding the consequences of implemented policies or initiatives in a policy environment where the past is too quickly dismissed due to the focus being placed on the new.

Argyris and Schön [119] discuss learning in terms of single and double loops. Singleloop learning refers to assessments of actions leading to sufficient reflection and renewed action to improve on attempts to reach the expected results. Double-loop learning goes beyond this by also reflecting on the governing variables that impact which actions can be taken or are prioritized (e.g., norms and values). Double-loop learning can lead to changing the nature of adopted actions. Note that both loops can be interrupted or be kept from occurring for various reasons-this can lead to a learning deficit. Figure 2 represents the loops with interruptions.

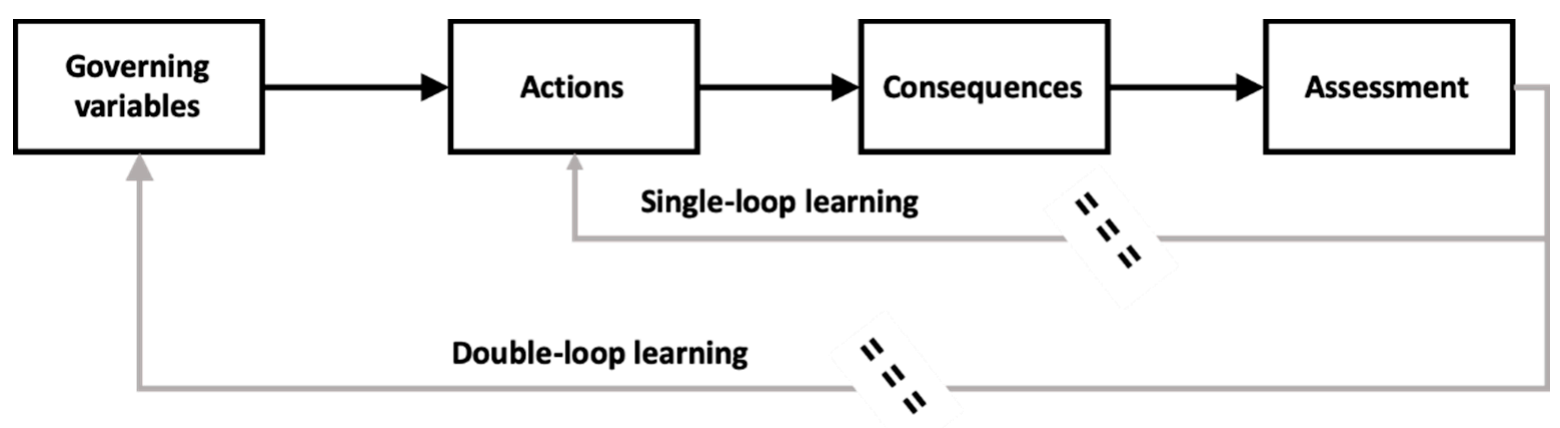

Figure 2. Single- and double-loop learning with interruptions (source: adapted from Argyris and Schön [119]).

Binding policy paradigms represent a problem for learning because they not only limit the range of governing variables and actions that are considered politically acceptabletherefore limiting the range of things that one can learn about and creating important interruptions in double-loop learning - they also limit the possibility of single-loop learning because the actions associated with their ideological principles are by default assumed to have positive results. In the case of innovation policy, this means that innovative actions are always supposed to be implemented, therefore creating a learning deficit on what would happen if one would maintain the established policies or would retrieve historical policies instead. It also means that it is not assessed whether implementing innovations is the best choice in the first place, as that is - after all—a core foundational belief of this specific binding policy paradigm. Sen [120] alerts to the risks of this type of approach. His insights lead one to conclude that less attention should be placed on the intrinsic characteristics of policies (e.g., whether they are innovative or not), but rather more on the extent to which they lead to actual societal improvements.

Overall, the tendency of innovation policy to dismiss historical lessons and anything that is perceived as retrieved from the past is a danger to learning in particular and to the quality of policy outcomes in general. There is broad consensus that "the end of history" 
has not actually occurred [121,122], and many historically retrieved elements are in fact at the core of many initiatives presented as "innovative" today (e.g., urban farming, cycling, or even the use of the internet, mapping, and data collection). Nevertheless, history has been largely removed from economic syllabuses [46], and innovation policy by definition refuses to support initiatives that do not at least make an attempt to highlight their difference to past initiatives, even if a closer examination shows that they are really about retrieval from the past. This "selling" of ideas as innovative is at best problematic because it asks for needless work, and at worst leads initiators to be less aware of, and inclined to research, valuable input from the past. This is likely to constitute a major driver of learning deficits.

\section{Conclusions}

This article has set out to question whether the EU's innovation-centred policy making achieves its self-set goals of sustainability, social inclusion, and economic growth. By conducting three different types of empirical research and a theoretical exploration based on the findings, the article concludes that it does-if one agrees that economic growth is a condition for social inclusion and sustainability, and that these can therefore be treated as by-products of a focus on economic growth. However, if one does not agree with this assumption (in line with authors such as Meadows et al. [44], Jackson [45], Raworth [46], Kallis [88], and Rosa and Henning [112]), innovation policy falls widely short of contributing to objectives of sustainability and especially social inclusion. Through the creation of a binding policy paradigm focused on innovation, such objectives are side-lined, setting the focus firmly on means (innovation, and even economic growth) instead of ends (e.g., human well-being). Economic growth, treated like an end though legitimized by its assumed function as a means, is the key objective that innovation policy highlights-perhaps unsurprisingly given its close connection to industrial interests. As this logic continues to be adopted, we witness an increasing level of social inequality and corporate control by a very limited number of stakeholders [123-125].

Further research is needed to establish whether the trends uncovered in this research are also found throughout most areas dominated by European innovation policy. A limitation of this research, which should also be addressed in further explorations, is that it focuses on policy documents at a high level and initiatives at a very small scaleinterpretations of innovation policy at intermediate levels could also be worthwhile to analyse. Furthermore, it could be interesting to study policies beyond those specifically focusing on innovation and seeing whether they balance out the negative effects of innovation policy, or whether they themselves tend to look for innovation within policies with other explicit aims (such as, for instance, poverty reduction, elderly care, or universal accessibility). Notwithstanding these remaining avenues for research, this article has contributed to highlighting problematic tendencies in EU policy making, which could be addressed in the particular areas studied, even if other findings would show differing tendencies elsewhere.

Although at the time of Henry Ford's invention of the assembly line for the fast production of cars, this could be considered an innovation, his quote in the introduction to this article shows how even he was a fierce critic of the logic of innovation that dominates contemporary policy making. In his book, Ford [1] argues firmly against—even ridiculescommon "salesmen's" wishes for constantly changing products for the sake of changing, without informing themselves well about the benefits and drawbacks of changes, and then deciding for or against them depending on the assessment. By 2020, and probably due to growing concerns about social acceleration and competitiveness, the EU seems to have sided with Ford's salesmen's logic. This has happened at the expense of urban planning policies' diversity and historical awareness, and has meant that the public interest is no longer thoroughly discussed nor made central to policy making. In line with authors such as Fougère et al. [11], Godin [13], Grisolia and Ferragina [15], Krüger [16], Sveiby et al. [18], Vinsel and Russel [19], and others, this article therefore suggests that innovation-based policy making be left behind. Instead, it proposes a return to a diverse, engaged, and 
historically aware policy-making practice explicitly in the name of objectives such as social inclusion, justice, well-being, and sustainability.

Author Contributions: Conceptualization, K.C.v.S. and A.F.; methodology, K.C.v.S. and A.F.; formal analysis, K.C.v.S. and A.F.; investigation, K.C.v.S. and A.F.; resources, K.C.v.S. and A.F.; data curation, K.C.v.S. and A.F.; writing—original draft preparation, K.C.v.S. and A.F.; writing-review and editing, K.C.v.S. and A.F.; visualization, K.C.v.S. and A.F; funding acquisition, K.C.v.S. All authors have read and agreed to the published version of the manuscript.

Funding: This research was funded by a WASS Strategic Funds LUP project number 2100939900 at Wageningen University and Research; the APC was funded by the R-LINK project "Redressing Long-term societal challenges through space for Incremental urban development, small-scale and bottom-up initiatives to produce New Knowledge for vital and inclusive urban regions" (NWO-SURF project 438-15-159).

Institutional Review Board Statement: Ethical review and approval were waived for this study, as the project was conducted prior to the national requirement. The project has approval from the National Research Organization NWO, project number 438-15-159.

Informed Consent Statement: Informed consent was obtained from all subjects involved in the study.

Acknowledgments: We would like to acknowledge the feedback of four anonymous reviewers and of the editors of the Special Issue, which were very helpful in improving the quality of the final manuscript. We also wish to thank Wageningen University and Research for the opportunity to critically explore this subject, including the direct support of Martha Bakker.

Conflicts of Interest: The authors declare no conflict of interest. The funders had no role in the design of the study; in the collection, analyses, or interpretation of data; in the writing of the manuscript, or in the decision to publish the results.

\section{Appendix A. Table of Scientific Publications on Innovation in Key Planning Journals Between 2015 and 2020}

To review how recent planning literature discusses innovation, five key planning journals and their articles on innovation published between 2015 and 2020 were reviewed. The selection criteria are outlined below, and Table A1 presents the results, including a brief description of the key message of each article.

Selection criteria for journals: the five highest ranking journals that include "planning" in their title in the SJR (Scopus Journal Ranking) ranking in December 2020 (noted for most recent ranking, which is of 2019). Note that planners publish in many other journals, and other sources were also reviewed, but this review was additionally conducted to provide a systematized overview concerning scientific planning literature of a particular time period. As a result, the following journals were selected: Environment and Planning D: Society and Space; Planning Theory: Environment and Planning A; Journal of the American Planning Association; and the Journal of Planning Literature.

Selection criteria for articles: use of the term "innovation" in title and published between 2015 and 2020 in the above-named journals. 
Table A1. Scientific publications in key planning journals with “innovation" in the title between 2015 and 2020 (compiled by authors).

\begin{tabular}{|c|c|c|c|c|c|}
\hline Author(s) & Title & Year & Key Message & Stance towards Innovation * & Reference \\
\hline \multicolumn{6}{|c|}{ Environment and Planning D: Society and Space (only one publication fit the criteria) } \\
\hline A. S. Rai & $\begin{array}{l}\text { The affect of Jugaad: Frugal innovation and postcolonial practice } \\
\text { in India's mobile phone ecology. }\end{array}$ & 2015 & $\begin{array}{l}\text { Linking geographical, temporal, and economic relationships } \\
\text { between affect and innovation }\end{array}$ & neutral & [126] \\
\hline \multicolumn{6}{|c|}{ Planning Theory (three publications fit the criteria) } \\
\hline $\begin{array}{l}\text { A. Agger and } \\
\text { E. Sørensen }\end{array}$ & Managing collaborative innovation in public bureaucracies. & 2016 & $\begin{array}{l}\text { Tasks and tensions emerging during collaborative } \\
\text { innovation management }\end{array}$ & neutral & [22] \\
\hline F. Bragaglia & $\begin{array}{l}\text { Social innovation as a 'magic concept' for policy-makers and its } \\
\text { implications for urban governance. }\end{array}$ & 2020 & $\begin{array}{l}\text { Discusses the appeal of social innovation discourses and logics, } \\
\text { but also their drawbacks }\end{array}$ & positive-critical & [10] \\
\hline E. Skrimizea & $\begin{array}{l}\text { Scale: The Universal Laws of Growth, Innovation, Sustainability, } \\
\text { and the Pace of Life in Organisms, Cities, Economies, and } \\
\text { Companies. [book review] }\end{array}$ & 2020 & $\begin{array}{l}\text { Praising book review, highlighting the book author's critical } \\
\text { view on the value of technological innovation, but as a } \\
\text { minor point }\end{array}$ & neutral-critical & [127] \\
\hline \multicolumn{6}{|c|}{ Environment and Planning A (sixteen publications fit the criteria) } \\
\hline R. H. W. Boyer & $\begin{array}{l}\text { Grassroots Innovation for Urban Sustainability: Comparing the } \\
\text { Diffusion Pathways of Three Ecovillage Projects }\end{array}$ & 2015 & $\begin{array}{l}\text { Unequal diffusion opportunities for grassroots innovations } \\
\text { and niche regime change initiatives }\end{array}$ & positive-neutral & [128] \\
\hline C. C. Wang & $\begin{array}{l}\text { Geography of Knowledge Sourcing, Search Breadth and } \\
\text { Depth Patters, and Innovative Performance: A Firm } \\
\text { Heterogeneity Perspective }\end{array}$ & 2015 & How knowledge sourcing affects innovation dynamics & positive-neutral & [129] \\
\hline $\begin{array}{l}\text { R. Shearmur and } \\
\text { D. Doloreux }\end{array}$ & $\begin{array}{l}\text { Central places or networks? Paradigms, metaphors, and spatial } \\
\text { configurations of innovation-related service use }\end{array}$ & 2015 & The importance of central places for innovation services & positive-neutral & [131] \\
\hline T. Wainwright & $\begin{array}{l}\text { Circulating financial innovation: new knowledge and } \\
\text { securitization in Europe }\end{array}$ & 2015 & $\begin{array}{l}\text { Critical review of the role of securitization in Europe after the } \\
\text { global financial crisis of } 2008\end{array}$ & neutral-critical & [132] \\
\hline $\begin{array}{l}\text { C. Corradini and } \\
\text { L. De Propris }\end{array}$ & $\begin{array}{l}\text { Technological diversification and new innovators in European } \\
\text { regions: evidence from patent data }\end{array}$ & 2015 & $\begin{array}{l}\text { Exploration of the transformative potential of diversity and } \\
\text { technological innovation through innovation }\end{array}$ & positive-neutral & [133] \\
\hline $\begin{array}{l}\text { A. Smith, T. } \\
\text { Hargreaves, S. } \\
\text { Hieschler, M. } \\
\text { Martiskainen, and } \\
\text { G. Seyfang }\end{array}$ & $\begin{array}{l}\text { Making the most of community energies: Three perspectives on } \\
\text { grassroots innovation }\end{array}$ & 2015 & $\begin{array}{l}\text { How to realize the full transformative potential of } \\
\text { grassroots innovations }\end{array}$ & positive & [134] \\
\hline $\begin{array}{l}\text { I. Liefner and } \\
\text { S. Jessberger }\end{array}$ & $\begin{array}{l}\text { The use of the analytical hierarchy process as a method of } \\
\text { comparing innovation across regions: The examples of the } \\
\text { equipment manufacturing industries of Shanghai and } \\
\text { Xiamen, China. }\end{array}$ & 2016 & $\begin{array}{l}\text { How innovation can be measured and compared } \\
\text { across regions }\end{array}$ & neutral-positive & [135] \\
\hline
\end{tabular}


Table A1. Cont.

\begin{tabular}{|c|c|c|c|c|c|}
\hline Author(s) & Title & Year & Key Message & Stance towards Innovation * & Reference \\
\hline $\begin{array}{l}\text { T. Wainwright and } \\
\text { G. Manville }\end{array}$ & $\begin{array}{l}\text { Financialization and the third sector: Innovation in social housing } \\
\text { bond markets }\end{array}$ & 2016 & $\begin{array}{l}\text { Critical review of impact of innovation through } \\
\text { financialization in housing bond markets in the UK }\end{array}$ & neutral-critical & [136] \\
\hline $\begin{array}{l}\text { V. Brinks, O. Ibert, } \\
\text { F. C. Müller, and } \\
\text { S. Schmidt }\end{array}$ & $\begin{array}{l}\text { From ignorance to innovation: Serendipity and purposeful } \\
\text { mobility in creative processes-The cases of biotechnology, legal } \\
\text { services and board games }\end{array}$ & 2018 & $\begin{array}{l}\text { Reconceptualizing creativity in terms of ignorance and } \\
\text { therefore reassessing the process of knowledge acquisition }\end{array}$ & neutral-positive & [137] \\
\hline $\begin{array}{l}\text { S. J. Herstad, } \\
\text { M.C.W. Solheim, } \\
\text { and M. Engen }\end{array}$ & $\begin{array}{l}\text { Learning through urban labour pools: Collected worker } \\
\text { experiences and innovation in services. }\end{array}$ & 2019 & How firms collect innovation potential through worker variety & positive-neutral & [138] \\
\hline J. Wang and Y. Tan & $\begin{array}{l}\text { Social factory as prosaic state space: Redefining labour in China's } \\
\text { mass innovation/mass entrepreneurship campaign }\end{array}$ & 2019 & $\begin{array}{l}\text { Critical review the impact of China's mass innovation/mass } \\
\text { entrepreneurship campaign }\end{array}$ & neutral-critical & [140] \\
\hline $\begin{array}{l}\text { J.-M. Lehmann } \\
\text { and P. Smets }\end{array}$ & $\begin{array}{l}\text { An innovative resilience approach: Financial self-help groups in } \\
\text { contemporary financial landscapes in the Netherlands }\end{array}$ & 2019 & Financial self-help as innovative resilience & positive & [141] \\
\hline C. Lorne & $\begin{array}{l}\text { The limits to openness: Co-working, design and social innovation } \\
\text { in the neoliberal city. }\end{array}$ & 2020 & $\begin{array}{l}\text { Critique of discourse of "openness"-in innovation, social } \\
\text { innovation, entrepreneurship, and more. The critique is } \\
\text { connected much more to the "openness" than innovation. }\end{array}$ & neutral-critical & [54] \\
\hline \multicolumn{6}{|c|}{ Journal of the American Planning Association (two publications fit the criteria, both book reviews) } \\
\hline T. C. Cornille & $\begin{array}{l}\text { Innovation in Public Transport Finance: Property Value Capture, } \\
\text { by Shishir Mathur: (2014). Farnham, Surry, UK: Ashgate. } 212 \\
\text { pages } \$ 109.95 \text { (hardcover). }\end{array}$ & 2015 & $\begin{array}{l}\text { Commending review of the book, saying that it makes } \\
\text { constructive and clarifying use of the concept of innovation }\end{array}$ & positive-neutral & [143] \\
\hline L. Lindsey & $\begin{array}{l}\text { Leading the Inclusive City: Place-Based Innovation for a Bounded } \\
\text { Planet, by Robin Hambleton: (2015). Chicago, IL: University of } \\
\text { Chicago Press. } 416 \text { pages. } \$ 44.95 \text { (paperback). }\end{array}$ & 2016 & $\begin{array}{l}\text { Critical review of the book about place-based innovation and } \\
\text { inclusion as not sufficiently inspirational, but both the book } \\
\text { and the review highlight innovation as positive }\end{array}$ & positive & [144] \\
\hline \multicolumn{6}{|c|}{ Journal of Planning Literature (two publications fit the criteria) } \\
\hline L. Fang & Do Clusters Encourage Innovation? A Meta-analysis. & 2015 & $\begin{array}{l}\text { How innovation can be encouraged and measured through } \\
\text { particular spatial configurations (i.e., clusters). }\end{array}$ & positive & [145] \\
\hline $\begin{array}{l}\text { A. Hagen and } \\
\text { U. Higdem }\end{array}$ & $\begin{array}{l}\text { Calculate, Communicate and Innovate: Do We Need "Innovate" as } \\
\text { a Third Position? }\end{array}$ & 2019 & $\begin{array}{l}\text { Literature review on the use of the concept of "innovation" in } \\
\text { planning theory from } 1945 \text { to } 2019 .\end{array}$ & neutral-positive & [21] \\
\hline
\end{tabular}

* Options: positive, neutral (i.e., assuming it is obvious that innovation should occur, the question is how), critical. 


\section{Appendix B. Table of Innovation-Based Urban Planning Project Search Results}

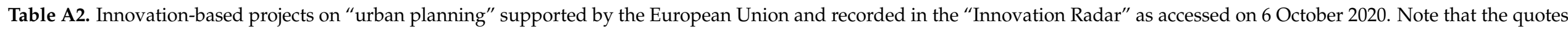

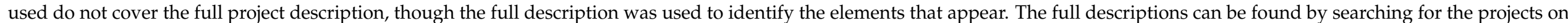
the innovation radar website: https://www.innoradar.eu.

Project Acronym, Title

\section{Description and End Date}

"MAKING-CITY is a large-scale demonstration project aiming at the development of new integrated strategies to address the urban energy system transformation towards low carbon cities, with the positive energy district (PED) approach as the core of the urban energy transition pathway. The

MAKING-CITY: Energy efficient pathway for the city transformation: enabling a positive future project will be intensively focused on achieving evidences about the actual potential of the PED concept, as foundation of a high efficient and sustainable route to progress beyond the current urban transformation roadmaps." (emphasis added)

End date: 30 November 2023

Promotion of: Sustainability Through: Efficiency

"SmartEnCity's main Objective is to develop a highly adaptable and replicable systemic approach towards urban transformation into sustainable smart and resource-efficient urban environments in Europe through the integrated planning and implementation of measures aimed at improving energy efficiency in main consuming sectors in cities, while increasing their supply of renewable energy, and demonstrate its benefits."

SmartEnCity (emphasis added)

End date: 31 July 2021

Promotion of: Sustainability, Social Inclusion, Economic Growth

Through: Efficiency, Digitalization and "Smart" Technologies

“The RUGGEDISED project will create urban spaces powered by secure, affordable and clean energy, smart electro-mobility, smart tools and services. The overall aims are: 1 . Improving the quality of life of the citizens, by offering the citizens a clean, safe, attractive, inclusive and affordable living environment. 2. Reducing the environmental impacts of activities, by achieving a significant reduction of $\mathrm{CO} 2$ emissions, a major increase in the investment and usage of RES and an increase in the deployment of electric vehicles. 3. Creating a stimulating environment for sustainable

Ruggedised: Rotterdam, Umea and Glasgow: Generating Exemplar Districts in Sustainable Energy Deployment economic development, by generating more sustainable jobs, stimulating community involvement in smart solutions and to boost start-up and

existing companies to exploit the opportunities of the green digital economy and Internet of Things." (emphasis added)

End date: 31 October 2021

Promotion of: Sustainability, Social Inclusion, Economic Growth

Through: Digitalization and "Smart" Technologies 
Table A2. Cont.

Project Acronym, Title

Water4Cities: Holistic Surface Water and Groundwater Management for Sustainable Cities

Sharing Cities

MiRTLE: Next generation, high performance, long range, standoff, concealed threat detection system to protect European citizens and critical infrastructure

\section{Description and End Date}

"The Water4Cities project will rely on sensor technologies, data and visual analytics to enable localization, visualization and analysis of urban water (both surface water and groundwater) at a holistic urban setting providing services to multiple water stakeholders. More specifically, the

Water4Cities project aims to develop the necessary models and associated platform that will enable water providers and relevant stakeholders to

(a) monitor in real-time the urban water resources; (b) support their decisions for optimal urban water management causing minimal environmental impact and (c) involve policy makers, corporations and the public to provide the support for sound and balanced decision-making. Beyond the scientific results, Water4Cities will target the exchange of knowledge among project partners."

End date: 28 February 2021

Promotion of: Sustainability, Social Inclusion

Through: Efficiency, Digitalization and "Smart" Technologies

"Sharing Cities has four key objectives. (1) To achieve scale in the European smart cities market by proving that properly designed smart city solutions, based around common needs, can be integrated in complex urban environments. [ ... ] (2) Adopt a digital first approach which proves the extent to which ICT integration can improve and connect up existing infrastructure, as well as the design and running of new city

infrastructure. [ ... ] (3) Accelerate the market to understand, develop and trial business, investment and governance models, essential for the true aggregation and replication (through collaboration) of smart city solutions in cities of different sizes and maturities. [ ... ] (4) Share and collaborate for society: to respond to increasing demand for participation; to enhance mechanisms for citizens' engagement; to improve local governments capacity for policy making and service delivery through collaboration and co-design; resulting in outcomes that are better for citizens,

businesses and visitors." (emphasis added)

End date: 31 December 2020

Promotion of: Sustainability, Social Inclusion/Participation, Economic Growth

Through: Digitalization and "Smart" Technologies, Behavioural Change

"Acts of terrorism aim to instil fear into Europe's citizens. Since 2000, approximately 163,000 people have died from global terrorism. [ ... ] Radio Physics Solutions Ltd. has developed MiRTLE (Millimetre-wave Radar Threat Level Evaluation), the world's first, high performance, long range (up to $50 \mathrm{~m}$ ), low cost, standoff "concealed threat" detection system for the protection of citizens and critical infrastructure. MiRTLE is capable of screening large groups of people automatically and autonomously, without operator intervention, in real-time. Our highly innovative system detects PBIEDs, guns (including 3D printed) and knives up to a range of 50m in real-time, with targets in motion, all without privacy concerns. The overall objective of this project is to successfully refine, scale-up and demonstrate our superior technology to our customer base. We are planning to capture an $8 \%$ market share of the improvised explosive devices (IED) and weapon detection market, which will in turn generate cumulative revenues of $€ 161 \mathrm{~m}$, cumulative EBITDA of $€ 43 \mathrm{~m}$ by 2025 and create 302 high skilled jobs in Europe." (emphasis added)

End date: 31 July 2020

Promotion of: Economic Growth

Through: Digitalization and "Smart" Technologies 
Table A2. Cont.

Project Acronym, Title

CIVITAS ECCENTRIC: Innovative solutions for sustainable mobility of people in suburban city districts and emission free freight logistics in urban centres.

PORTIS: PORT-Cities:

Integrating Sustainability

RISEN: Rail Infrastructure Systems Engineering Network

\section{Description and End Date}

"The cities of Madrid, Stockholm, Munich, Turku and Ruse have formed the CIVITAS ECCENTRIC consortium to tackle the challenges of mobility in suburban districts and clean, silent and CO2 free city logistics. [ . . . ] ECCENTRIC will demonstrate and test the potential and replicability of integrated and inclusive urban planning approaches, innovative policies and emerging technologies to reach sustainable urban mobility objectives.

The solutions will be implemented in 5 living laboratory areas in the outskirts that face high population growth and an increasing pressure on the existing transport networks. [ ... ] To reach CO2 free city logistics by 2030, ECCENTRIC will test clean vehicles and fuels, formulate new regulations and services and develop consolidation solutions in close partnerships with the private sector" (emphasis added)

End date: 31 August 2020

Promotion of: Sustainability, Social Inclusion

Through: Digitalization and "Smart" Technologies (relatively little, exceptional)

"Thanks to the Civitas Initiative, the partner cities expect to prove that more efficient and sustainable mobility is conducive to the establishment of vital and multi-modal hubs for urban, regional, national and International movements of passengers and goods. To do this, they establish integrated living laboratories clustering local measures according to four major aspects of sustainable urban mobility: 1 . Governance: to increase port-city collaborative planning and participation, leading to enhanced forms of SUMPs. 2. People: to foster less car-dependent mobility styles, leading to modal shift in favour of collective and more active transport. 3. Transport system: to strengthen the efficiency of road traffic management to/from the port and through the city, and foster the use of clean vehicles. 4. Goods: to enhance logistics and freight transport, improving the efficiency and coordination of city, port and regional freight movements." (emphasis added)

End date: 31 August 2020

Promotion of: Sustainability, Social Inclusion

Through: Efficiency, Digitalization and "Smart" Technologies, Behavioural Change

"Social and economic growth, security and sustainability in Europe are at risk of being compromised due to aging and failing railway infrastructure systems. This partly reflects a recognised skill shortage in railway infrastructure engineering. This project, RISEN, aims to enhance knowledge creation and transfer using both international and intersectoral secondment mechanisms [... ] This project adds research skill mobility and innovation dimension to existing bilateral collaborations between universities through research exchange, joint research supervision, summer courses, international training and workshops, and joint development of innovative inventions. [ ... ] RISEN aims to produce the next generation of engineers and scientists needed to meet the challenge of providing sustainable, smart and resilient railway infrastructure systems critical for maintaining European competitiveness. The emphasis will be placed on the resilience and adaptation of railway and urban transport infrastructures using integrated smart systems."

End date: 31 March 2020

Promotion of: Sustainability, Economic Growth

Through: Digitalization and "Smart" Technologies (relatively little, exceptional) 
Table A2. Cont.

Project Acronym, Title

PULSE: Participatory Urban Living for Sustainable Environments

smarticipate: smart services for calculated impact assessment in open governance

PROSFET: Promoting Sustainable Freigh Transport in Urban Contexts: Policy and Decision-Making Approaches

DECADE: Deploying High Capacity Dense Small Cell Heterogeneous Networks

\section{Description and End Date}

“PULSE (Participatory Urban Living for Sustainable Environments) will leverage diverse data sources and big data analytics to transform public health from a reactive to a predictive system, and from a system focused on surveillance to an inclusive and collaborative system supporting health equity. Working within five global cities, PULSE will harvest open city data, and data from health systems, urban and remote sensors, personal devices and social media to enable evidence-driven and timely management of public health events and processes."

End date: 31 October 2019

Promotion of: Sustainability, Social Inclusion

Through: Efficiency, Digitalization and "Smart" Technologies

"SMARTICIPATE is a data-rich citizen dialogue system, transforming public data into new intelligence, and transposing elements of intelligent ICT development to urban governance. The aim is to integrate bottom-up processes in the realm of city planning, using the full potential of citizens by sharing ideas in the co-production of decision making. smarticipate thereby transforms interaction between citizens, businesses and public administrations in the management of cities, providing a must-have tool that improves cities' performance, leverages government-citizen relationships, reduces burdens on government via co-production of tasks, and saves money through increased efficiency of processes." (emphasis added)

End date: 31 January 2019

Promotion of: Social Inclusion, Economic Growth

Through: Efficiency, Digitalization and "Smart" Technologies

"Within a context of growing urban population, advances in urban logistics operations and improved local authority planning, especially in the field of the urban freight transport, can alleviate the associated negative environmental and economic impacts occurring in cities. [ ... ] The proposed project will be aimed at identifying local authority planning needs with regards to urban/city logistics activities and the necessary pre-requisites for inclusion of stakeholders in the process. Finally, the project will promote the knowledge transfer of methods and models through the conceptual development of a novel decision support tool (thanks to involved software houses)."

End date: 31 December 2019

Promotion of: Sustainability, Social Inclusion

Through: Efficiency, Digitalization and "Smart" Technologies

“The DECADE project adopts the scheme of Research and Innovation Staff Exchange (RISE), with the effect of inter-sectorial efforts and knowledge integration to tackle the challenges [exponential traffic growth] in HetNet [Heterogenous Networks] planning and optimization. The research consists in fundamental capacity analysis, system modeling, algorithm development, and performance engineering for HetNets. In addition,

DECADE serves as a solid platform to promote long-term collaboration between academia and industry collaboration in a rapidly evolving area of Information and Communication Technologies (ICT) in Europe." (emphasis added)

End date: 31 July 2019

Promotion of: Social Inclusion, Economic Growth

Through: Efficiency, Digitalization and "Smart" Technologies 
Table A2. Cont.

Project Acronym, Title

I-Media-Cities: Innovative e-environment for Research on Cities and the Media

OrganiCity-Co-creating smart cities of the future

URBIS: URBan land recycling Information services for Sustainable cities

SmartH2O: an ICT Platform to leverage on Social Computing for the efficient management of Water Consumption

\section{Description and End Date}

"At the end of the project, we will deliver a digital content access platform (interoperable and multilingual), made available to a growing community of researchers and creatives Europe-wide to push the boundaries of what we can learn, through AV [Audio-Visual] material on cities, on European history and identity. The legacy of I-Media-Cities will be a new model for research on digital sources (applicable also to other subject areas), plus appropriate exploitation plans to consolidate and expand the platform into the European reference initiative on AV digital content." End date: 31 March 2019

Promotion of: Social Inclusion, Economic Growth

Through: Digitalization and "Smart" Technologies

"[ ... ] this project seeks to build a strong foundation for future sustainable cities through co-creation by a wide range of stakeholders. [ ... ] By focusing on the city as a sociotechnical whole, OrganiCity brings software, hardware and associated human processes flexibly together into a new living city that is replicable, scalable, as well as socially, environmentally and economically sustainable. [ ... ] The OrganiCity consortium will create a novel set of tools for civic co-creation, well beyond the state of the art in trans-disciplinary participatory urban interaction design. [ ... ] The aim is to grow sustainable digital solutions for future cities that are adjusted to the culture and capacities of each city unlocking amended services and novel markets."

End date: 30 June 2018

Promotion of: Sustainability, Social Inclusion, Economic Growth

Through: Digitalization and "Smart" Technologies

"The URBIS project aims to develop, implement and validate in real environment innovative information services related to urban vacant land, based on open geospatial data, to support planning of European Large Urban Zone's (LUZs) in a sustainable way. [ ... ] In particular, the so called Fast Track Services (FTS) on Land Monitoring are currently being developed to include new more detailed layers of information focused on urban and forest areas which will be essential for the development of an information service aimed at identifying and characterising vacant and derelict urban sites. The development of such an information service could play a major role in the promotion of recycling existing urban sites thus contributing to the reduction of urban sprawl."

End date: 31 March 2017

Promotion of: Sustainability

Through: Digitalization and "Smart" Technologies

"The SmartH2O project aims at providing water utilities, the municipalities, and citizens, with an ICT enabled platform to design, develop and implement better water demand management policies, which are based on a shared understanding and motivation by the water users, thus leading to a reduction in water consumption, while not compromising the quality of life. SmartH2O builds a bi-directional communication stream between citizens and the water utility: in one direction, user behavioural data are collected through smart meters and an online social participation

application (social game); in the other, awareness campaigns and price signals are delivered through the same app to inform the users on how to save water and money."

End date: 31 March 2017

Promotion of: Sustainability, Social Inclusion

Through: Digitalization and "Smart" Technologies, Behavioural Change 
Table A2. Cont.

Project Acronym, Title

INDICATE: Indicator-based Interactive Decision Support and Information

Exchange Platform for Smart Cities

MyWay: European Smart Mobility Resource Manager

DIMMER: District Information Modeling and Management for Energy Reduction

\section{MOBINCITY: SMART MOBILITY IN} SMART CITY

\section{Description and End Date}

"INDICATE proposes a novel city-wide decision support system which accounts for all major systems and activities relevant to developing energy-efficient cities. [ . . . ] INDICATE addresses these issues through the development of a decision support tool that is used in all stages of urban development of a city. [ . . . ] This is achieved through the integration of Dynamic Simulation Modelling, Geographic Information Systems (GIS), 3D Urban CAD Modelling Tools, Sustainable Urban Indicators and algorithms for Demand Side Management and local balancing of energy use into a single software package."

End date: 30 September 2016

Promotion of: Sustainability, Economic Growth

Through: Efficiency, Digitalization and "Smart" Technologies

“[ ... ] MyWay will investigate, develop and validate an integrated platform, the European Smart Mobility Resource Manager, including cloud-based services and facilities to support community supplied information collection and processing. The purpose is to holistically address the efficient and seamless integration and use of complementary, capacity-limited mobility services in the overall urban travel chain, including all transport modes (motorised and non-motorised, EVs, public transport, flexible services such as transport on-demand) and mobility sharing schemes (e.g., car sharing, motorbike sharing and carpooling). [ . . . ] The approach gives priority to the egocentric vision of the user, finding the right compromise for each single traveller and offering a solution closest to his personal needs and preferences, making the frequent use of it (as an alternative to an ideal but not always practical solution) a main contribution to the sustainability of urban transport."

End date: 29 February 2016

Promotion of: Sustainability

Through: Efficiency, Digitalization and “Smart" Technologies, Behavioural Change

"The DIMMER system integrates BIM and district level 3D models with real-time data from sensors and user feedback to analyse and correlate buildings utilization and provide real-time feedback about energy-related behaviors. It allows open access with personal devices and Augmented Reality (A/R) visualization of energy-related information to client applications for energy and cost-analysis, tariff planning and evaluation, failure identification and maintenance, energy information sharing. [ . . . ] the expected results are a consistent reduction in both energy consume and CO2 emissions by enabling a more efficient energy distribution policies, according to the real characteristics of district buildings and inhabitants as wel as a more efficient utilization and maintenance of the energy distribution network, based on social behavior and users attitudes and demand."

End date: 30 September 2016

Promotion of: Sustainability

Through: Efficiency, Digitalization and "Smart" Technologies, Behavioural Change

"MOBINCITY aims at the optimization of FEV autonomy range and the increase in energy efficiency thanks to the development of a complete ICT-based integrated system able to interact between driver, vehicle and transport and energy infrastructures, taking advantage of the information provided from these sources in order to optimise both energy charging and discharging processes (trip planning and routing)."

End date: 30 June 2015

Promotion of: Sustainability

Through: Efficiency, Digitalization and "Smart” Technologies, Behavioural Change 


\section{References}

1. Ford, H. My Life and Work; Doubleday, Page \& Company: New York, NY, USA, 1922.

2. European Commission. Mission-Oriented Research E Innovation in the European Union: A Problem-Solving Approach to Fuel InnovationLed Growth; European Commission: Brussels, Belgium, 2018.

3. European Commission Identifying Barriers to Innovation. European Commission. Available online: https://ec.europa.eu/info/researchand-innovation/law-and-regulations/innovation-friendly-legislation/identifying-barriers_en (accessed on 6 October 2020).

4. European Commission. This Is European Social Innovation; European Commission: Brussels, Belgium, 2010.

5. European Commission. Better Regulation Guidelines. Commission Staff Working Document. European Commission. 2017. Available online: https:/ / ec.europa.eu/info/sites/info/files/better-regulation-guidelines.pdf (accessed on 15 January 2021).

6. European Commission Innovation Principle Makes EU Laws Smarter and Future-Oriented, Experts Say. European Commission. Available online: https:/ / ec.europa.eu/info/news/innovation-principle-makes-eu-laws-smarter-and-future-oriented-expertssay-2019-nov-25_en (accessed on 8 October 2020).

7. European Commission. Better Regulations for Innovation-Driven Investment at EU Level: Commission Staff Working Document; European Commission; Directorate General for Research and Innovation: Brussels, Belgium, 2016.

8. Moulaert, F.; MacCallum, D.; Mehmood, A.; Hamdouch, A. (Eds.) The International Handbook on Social Innovation: Collective Action, Social Learning and Transdisciplinary Research; Edward Elgar: Cheltenham, UK, 2013.

9. Moulaert, F.; Mehmood, A.; MacCallum, D.; Leubolt, B. Social Innovation as a Trigger for Transformations-The Role of Research; EU Publications Office: Luxemburg, 2017; ISBN 978-92-79-68440-1.

10. Bragaglia, F. Social Innovation as a 'Magic Concept' for Policy-Makers and Its Implications for Urban Governance. Plan. Theory 2020. [CrossRef]

11. Fougère, M.; Segercrantz, B.; Seeck, H. A Critical Reading of the European Union's Social Innovation Policy Discourse: (Re)Legitimizing Neoliberalism. Organization 2017, 24, 819-843. [CrossRef]

12. Fougère, M.; Meriläinen, E. Exposing Three Dark Sides of Social Innovation through Critical Perspectives on Resilience. Ind. Innov. 2019, 1-18. [CrossRef]

13. Godin, B. Innovation Contested: The Idea of Innovation over the Centuries; Routledge: London, UK, 2015.

14. Godin, B.; Vinck, D. (Eds.) Critical Studies of Innovation: Alternative Approaches to the Pro-Innovation Bias; Edward Elgar Publishing Limited: Cheltenham, UK, 2017.

15. Grisolia, F.; Ferragina, E. Social Innovation on the Rise: Yet Another Buzzword in Time of Austerity? Salute e Sociéta 2015, 71-84. [CrossRef]

16. Krüger, T. Wider den Innovationsimperativ! Eine Kritik am Konzept der sozialen Innovation aus Postwachstumsperspektive. In Postwachstumsstadt_Konturen einer solidarischen Stadtpolitik; Brokow-Loga, A., Eckardt, F., Eds.; Oekom Verlag: München, Germany, 2020; pp. 120-137.

17. Lijster, T. The Future of the New: Artistic Innovation in Times of Social Acceleration; Valiz: Amsterdam, The Netherlands, 2018.

18. Sveiby, K.-E.; Gripenberg, P.; Segercrantz, B. (Eds.) Challenging the Innovation Paradigm; Taylor \& Francis: New York, NY, USA, 2012.

19. Vinsel, L.; Russel, A. The Innovation Delusion. How Our Obsession with the New Has Disrupted the Work That Matters Most; Penguin Random House LLC: New York, NY, USA, 2020.

20. Uyarra, E.; Flanagan, K.; Magro, E.; Zabala-Iturriagagoitia, J.M. Anchoring the Innovation Impacts of Public Procurement to Place: The Role of Conversations. Environ. Plan. C Politics Space 2017, 35, 828-848. [CrossRef]

21. Hagen, A.; Higdem, U. Calculate, Communicate, and Innovate: Do We Need "Innovate" as a Third Position? J. Plan. Lit. 2019, 34, 421-433. [CrossRef]

22. Agger, A.; Sørensen, E. Managing Collaborative Innovation in Public Bureaucracies. Plan. Theory 2018, 17, 53-73. [CrossRef]

23. Garnett, K.; Van Calster, G.; Reins, L. Towards an Innovation Principle: An Industry Trump or Shortening the Odds on Environmental Protection? Lawinnovation Technol. 2018, 10, 1-14. [CrossRef]

24. Krüger, T.; Pellicer-Sifres, V. From Innovations to Exnovations. Conflicts, (De-)Politicization Processes, and Power Relations Are Key in Analysing the Ecological Crisis. Innov. Eur. J. Soc. Sci. Res. 2020, 33, 115-123. [CrossRef]

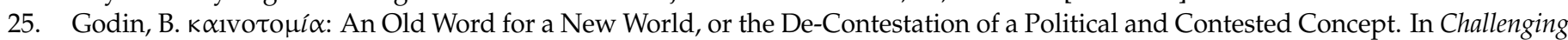
the Innovation Paradigm; Sveiby, K.-E., Gripenberg, P., Segercrantz, B., Eds.; Routledge: New York, NY, USA, 2012 ; pp. 37-60.

26. Ferreira, A.; von Schönfeld, K.C.; Tan, W.; Papa, E. Maladaptive Planning and the Pro-Innovation Bias: Considering the Case of Automated Vehicles. Urban Sci. 2020, 4, 41. [CrossRef]

27. Sie, R.L.; Bitter-Rijpkema, M.; Stoyanov, S.; Sloep, P.B. Factors That Influence Cooperation in Networks for Innovation and Learning. Comput. Hum. Behav. 2014, 37, 377-384. [CrossRef]

28. Sol, J.; Beers, P.J.; Wals, A.E.J. Social Learning in Regional Innovation Networks: Trust, Commitment and Reframing as Emergent Properties of Interaction. J. Clean. Prod. 2013, 49, 35-43. [CrossRef]

29. Butzin, A.; Rabadjieva, M. Soziale Innovationen in Mobilität Und Verkehr-Was Sind Sie Und Wer Macht Sie? In Forschung Aktuell Institut Arbeit und Technik; Institut Arbeit und Technik (IAT): Gelsenkirchen, Germany, 2018; Volume 1.

30. Merkel, S. Applying the Concept of Social Innovation to Population-Based Healthcare. Eur. Plan. Stud. 2018, 28, 978-990. [CrossRef]

31. Kaya, T.; Erkut, B.; Thierbach, N. Entrepreneurial Intentions of Business and Economics Students in Germany and Cyprus: A Cross-Cultural Comparison. Sustainability 2019, 11, 1437. [CrossRef] 
32. Diercks, G.; Larsen, H.; Steward, F. Transformative Innovation Policy: Addressing Variety in an Emerging Policy Paradigm. Res. Policy 2019, 48, 880-894. [CrossRef]

33. Kirwan, J.; Ilbery, B.; Maye, D.; Carey, J. Grassroots Social Innovations and Food Localisation: An Investigation of the Local Food Programme in England. Glob. Environ. Chang. 2013, 23, 830-837. [CrossRef]

34. Engelbrecht, H.J. The (Social) Innovation-Subjective Well-Being Nexus: Subjective Well-Being Impacts as an Additional Assessment Metric of Technological and Social Innovations. Innovation 2017, 31, 317-332. [CrossRef]

35. Council of the European Communities (Ed.) Treaty of Maastricht (Treaty on European Union); Office for Official Publications of the European Communities: Luxembourg; UNIPUB [distributor]: Lanham, MD, USA, 1992; ISBN 978-92-824-0959-6.

36. European Union. Treaty of Lisbon; European Union: Brussels, Belgium, 2009.

37. Brundtland Commission Our Common Future. World Commission on Environment and Development; Cambridge University Press: Cambridge, UK, 1987.

38. Etzkowitz, H. Innovation in Innovation: The Triple Helix of University-Industry-Government Relations. Soc. Sci. Inf. 2003, 42, 293-337. [CrossRef]

39. Etzkowitz, H.; Leydesdorff, L. The Endless Transition: A “Triple Helix" of University-Industry-Government Relations. Minerva 1989, 36, 203-208.

40. Etzkowitz, H.; Leydesdorff, L. Universities and Global Knowledge Economy: A Triple Helix of University-Industry-Government; Continuum: London, UK, 2001.

41. Marcovich, A.; Shinn, T. From the Triple Helix to a Quadruple Helix? The Case of Dip-Pen Nanolithography. Minerva 2011, 49, 175-190. [CrossRef]

42. Parveen, S.; Senin, A.A.; Umar, A. Organization Culture and Open Innovation: A Quadruple Helix Open Innovation Model Approach. Int. J. Econ. Financial Issues 2015, 5, 8.

43. Vallance, P.; Tewdwr-Jones, M.; Kempton, L. Building Collaborative Platforms for Urban Innovation: Newcastle City Futures as a Quadruple Helix Intermediary. Eur. Urban Reg. Stud. 2020, 27, 325-341. [CrossRef]

44. Meadows, D.H.; Meadows, D.L.; Randers, J.; Behrens III, W.W. The Limits to Growth. A Report for The Club of Rome's Project on the Predicament of Mankind; Universe Books: New York, NY, USA, 1972.

45. Jackson, T. Prosperity without Growth; Earthscan: London, UK, 2009.

46. Raworth, K. Doughnut Economics: Seven Ways to Think Like a 21st-Century Economist; Penguin Random House UK: London, UK, 2017.

47. Morgan, T. The Techno-Finance Fix: A Critical Analysis of International and Regional Environmental Policy Documents and Their Implications for Planning. Prog. Plan. 2018, 119, 1-29. [CrossRef]

48. Bensuade Vincent, B. The Politics of Buzzwords at the Interface of Technoscience, Market and Society: The Case of 'Public Engagement in Science'. Public Underst. Sci. 2014, 23, 238-253. [CrossRef]

49. Hasu, M.; Leitner, K.-H.; Solitander, N.; Verblane, U. Accelerating the Innovation Race: Do We Need Reflexive Brakes? In Challenging the Innovation Praradigm; Sveiby, K.-E., Gripenberg, P., Segercrantz, B., Eds.; Routledge: London, UK, 2012 ; pp. 87-112.

50. Rosa, H. Available, accessible, attainable. The mindset of growth and the resonance conception of the good life. In The Good Life Beyond Growth. New Perspectives; Rosa, H., Henning, C., Eds.; Routledge: Oxon, UK, 2018.

51. Lennon, M. On 'the Subject' of Planning's Public Interest. Plan. Theory 2017, 16, 150-168. [CrossRef]

52. Foroobar, R. Don't Be Evil: The Case Against Big Tech.; Penguin: London, UK, 2019.

53. Zuboff, S. The Age of Surveillance Capitalism: The Fight for a Human Future at the New Frontier of Power; Profile Books: London, UK, 2019.

54. Lorne, C. The Limits to Openness: Co-Working, Design and Social Innovation in the Neoliberal City. Environ. Plan. A Econ. Space 2020, 52, 747-765. [CrossRef]

55. Fraser, N. Can Society Be Commodities All the Way down? Post-Polanyian Reflections on Capitalist Crisis. Econ. Soc. 2014, 43, 541-558. [CrossRef]

56. European Commission Policies. European Commission. Available online: https://ec.europa.eu/info/policies_en (accessed on 24 October 2020).

57. European Union Goals and Values of the EU. European Union. Available online: https://europa.eu/european-union/about-eu/ eu-in-brief_en (accessed on 24 October 2020).

58. Pfotenhauer, S.M.; Juhl, J.; Aarden, E. Challenging the "Deficit Model" of Innovation: Framing Policy Issues under the Innovation Imperative. Res. Policy 2018, 1-10. [CrossRef]

59. Bryman, A. Social Research Methods, 4th ed.; Oxford University Press: Oxford, UK, 2012.

60. European Commission 6 Commission Priorities for 2019-24. European Commission. Available online: https://ec.europa.eu/info/ strategy/priorities-2019-2024_en (accessed on 11 October 2020).

61. European Commission. Study Supporting the Interim Evaluation of the Innovation Principle: Final Report; European Commission; Publications Office of the European Union, European Union: Luxemburg, 2019.

62. von der Leyen, U. A Union That Strives for More. My Agenda for Europe. Political Guidelines for the Next European Commission 2019-2024 2019. European Commission. Available online: https:/ / ec.europa.eu/info/sites/info/files/political-guidelines-nextcommission_en_0.pdf (accessed on 25 October 2020). 
63. European Commission Research \& Innovation. European Commission. Available online: https://ec.europa.eu/info/strategy/ research-and-innovation_en (accessed on 25 October 2020).

64. eurostat Glossary: Innovation. European Commission. Available online: https://ec.europa.eu/eurostat/statistics-explained/index. php/Glossary:Innovation (accessed on 6 October 2020).

65. Gouardères, F. Innovation Policy 2020. European Parliament. Available online: https://www.europarl.europa.eu/factsheets/en/ sheet/67/innovation-policy (accessed on 6 October 2020).

66. eip-agri What Is Innovation? European Commission. Available online: https://ec.europa.eu/eip/agriculture/en/what-innovation (accessed on 6 October 2020).

67. European Ccommission Social Innovation. European Commission. Available online: https://ec.europa.eu/social/main.jsp?catId= 1022\&langId=en (accessed on 6 October 2020).

68. European Commission Ensuring EU Legislation Supports Innovation. European Commission. Available online: https:/ / ec.europa. eu/info/research-and-innovation/law-and-regulations/innovation-friendly-legislation_en (accessed on 6 October 2020).

69. Ziomek, E. The Innovation Principle-Factsheet 2019. European Commission. Available online: https://ec.europa.eu/info/ research-and-innovation/law-and-regulations/innovation-friendly-legislation_en (accessed on 6 October 2020).

70. Bayer, A.G.; Basf, S.E.; Curis GmbH; The Dow Chemical Company; Dow Corning Corporation; Dow AgroScience LLS; Henkel AG \& Company; IBM Europe; Novartis, A.G.; Royal Philips; et al. The Innovation Principle. "Stimulating Economic Recovery". Open Letter to José Manuel Barroso. 2013. Available online: https:/ / corporateeurope.org/sites/default/files/corporation_letter_ on_innovation_principle.pdf (accessed on 9 October 2020).

71. Corporate Europe Observatory The "innovation Principle" Trap. Industries behind Risky Products Push for Backdoor to Bypass EU Safety Rules. Corporate Europe Observatory. Available online: https://corporateeurope.org/en/environment/2018/12/ innovation-principle-trap (accessed on 9 October 2020).

72. Leroux, J. The "Innovation Principle" Is a Regulatory Trojan Horse from the Industry. The Greens/EFA in the European Parliament. Available online: https: / / www.greens-efa.eu/en/article/news/the-innovation-principle-is-a-regulatory-trojan-horse-fromthe-industry/ (accessed on 9 October 2020).

73. European Commission The European Innovation Council (EIC). European Commission. Available online: https://ec.europa.eu/ info/files/european-innovation-council-eic_en (accessed on 25 October 2020).

74. European Commission European Innovation Partnerships (EIPs) Definition and Context 2015. Available online: https://s3 platform.jrc.ec.europa.eu/documents /20182/117542/S2E_Fiche_EIPs.pdf/ca0e86c7-b344-48e9-b7a4-678f79fc0c76 (accessed on 30 October 2020).

75. EIT Knowledge and Innovation Communities: What Is an Innovation Community? European Institute of Innovation and Technology. Available online: https:/ / eit.europa.eu/our-communities/eit-innovation-communities (accessed on 25 October 2020).

76. EIT Vision and Mission. European Institute of Innovation and Technology. Available online: https:/ / eit.europa.eu/who-we-are/eitglance/mission (accessed on 25 October 2020).

77. European Commission Commission Notice: Guidance on Innovation Procurement 2018. European Commission. Available online: https:/ / ec.europa.eu/transparency/regdoc/rep/3/2018/EN/C-2018-3051-F1-EN-MAIN-PART-1.PDF (accessed on 8 October 2020).

78. European Commission Commission Advises Public Buyers on How to Capitalise Innovation. European Commission. Available online: https: / /ec.europa.eu/growth/content/commission-advises-public-buyers-how-capitalise-innovation_en (accessed on 8 October 2020).

79. European Commission Innovation Procurement. European Commission. Available online: https://ec.europa.eu/info/policies/ public-procurement/support-tools-public-buyers/innovation-procurement_en (accessed on 8 October 2020).

80. European Commission European Innovation Scoreboard. European Commission. Available online: https://ec.europa.eu/growth/ industry / policy/innovation/scoreboards_en (accessed on 25 October 2020).

81. Hollanders, H.; Es-Sadki, N.; Merkelback, I. Khalilova European Innovation Scoreboard 2020. Available online: https:/ / ec.europa. eu/docsroom/documents/ 42981 (accessed on 25 October 2020).

82. European Commission Better Regulation: Guidelines and Toolbox. European Commission. Available online: https: / / ec.europa.eu/info/law/law-making-process/planning-and-proposing-law / better-regulation-why-and-how / betterregulation-guidelines-and-toolbox_en (accessed on 25 October 2020).

83. European Commission Better Regulation Toolbox. European Commission. Available online: https://ec.europa.eu/info/law/lawmaking-process / planning-and-proposing-law / better-regulation-why-and-how / better-regulation-guidelines-and-toolbox / better-regulation-toolbox_en (accessed on 30 October 2020).

84. European Commission Tool \#21. Research \& Innovation. European Commission. Available online: https:/ / ec.europa.eu/info/ law / law-making-process / planning-and-proposing-law / better-regulation-why-and-how / better-regulation-guidelines-andtoolbox/better-regulation-toolbox_en (accessed on 6 October 2020).

85. European Commission The Innovation Radar. European Commission. Available online: https://ec.europa.eu/digital-singlemarket/en/innovation-radar (accessed on 25 October 2020).

86. European Commission Missions in Horizon Europe. European Commission. Available online: https://ec.europa.eu/info/horizoneurope/missions-horizon-europe_en (accessed on 30 October 2020). 
87. European Commission Proposed Mission: 100 Climate-Neutral Cities by 2030-by and for the Citizens. Report of the Mission Board for Climate-Neutral and Smart Cities 2020. European Commission. Available online: https:/ / ec.europa.eu/info/sites/info/files/ research_and_innovation/funding/documents/ec_rtd_mission-board-report-climate-neutral-and-smart-cities.pdf (accessed on 30 October 2020).

88. Kallis, G. Degrowth; Agenda Publishing Limited: Newcastle upon Tyne, UK, 2018.

89. European Commission Horizon Prize for Social Innovation: Improved Mobility for Older People. Rules of the Contest 2017. European Commission. Available online: https:/ / ec.europa.eu/info/news/horizon-prize-social-innovation-commission-awardsthree-outstanding-projects-2019-sep-24_en (accessed on 25 October 2020).

90. European Commission Horizon Prize for Social Innovation: Commission Awards Three Outstanding Projects. European Commission. Available online: https:/ / ec.europa.eu/info/news/horizon-prize-social-innovation-commission-awards-threeoutstanding-projects-2019-sep-24_en (accessed on 25 October 2020).

91. Russell, A.; Meyerson, J.; Vinsel, L.; Dapena Fraiz, L. Welcome. The Maintainers. Available online: https://themaintainers.org/ (accessed on 25 October 2020).

92. Alcott, B. Jevon's Paradox. Ecol. Econ. 2005, 54, 9-21. [CrossRef]

93. Figge, F.; Young, W.; Barkmeyer, R. Sufficiency or Efficiency to Achieve Lower Resource Consumption and Emissions? The Role of the Rebound Effect. J. Clean. Prod. 2014, 69, 216-224. [CrossRef]

94. Sorrell, S. Jevon's Paradox Revisited: The Evidence for Backfire from Improved Energy Efficiency. Energy Policy 2009, 37, 1456-1469. [CrossRef]

95. Bina, O.; Inch, A.; Pereira, L. Beyond Techno-Utopia and Its Discontents: On the Role of Utopianism and Speculative Fiction in Shaping Alternatives to the Smart City Imaginary. Futures 2020, 115. [CrossRef]

96. Krivy, M. Towards a Critique of Cybernetic Urbanism: The Smart City and the Society of Control. Planning Theory 2016. [CrossRef]

97. Shove, E. Beyond the ABC: Climate Change Policy and Theories of Social Change. Environ. Plan. A 2010, 42, 1273-1285. [CrossRef]

98. Shove, E.; Pantzar, M.; Watson, M. The Dynamics of Social Practice: Everday Life and How It Changes; SAGE Publications Ltd.: London, UK, 2012.

99. Urban, J.B.; Hargraves, M.; Trochim, W.M. Evolutionary Evaluation: Implications for Evaluators, Researchers, Practitioners, Funders and the Evidence-Based Program Mandate. Eval. Program Plan. 2014, 45, 127-139. [CrossRef] [PubMed]

100. Copenhagenize.com Bicycle Innovation Lab—Denmark's First Cultural Centre for Bicycle Culture. Available online: http: //www.copenhagenize.com/2011/11/bicycle-innovation-lab-cultural-centre.html (accessed on 3 November 2020).

101. Copenhagenize.com Innovative Elevated Cycle Track in Copenhagen. Copenhagenize. 2011. Available online: http://www. copenhagenize.com/2011/12/innovative-elevated-cycle-track-in.html (accessed on 3 November 2020).

102. Everett, H. "Future Cycling" Conference: Multi-Billion Pound Investments Could Be Made Available for EU Cycling Strategy. Cycling Industry. Available online: https: / / cyclingindustry.news/future-cycling-conference-eu-strategy / (accessed on 3 November 2020).

103. TransportXtra How Cycling and Walking Innovation Is Boosting Industry and the Economy. Transportxtra. Available online: https:/ / www.transportxtra.com/publications/local-transport-today/news/59516/how-cycling-and-walking-innovationis-boosting-industry-and-the-economy (accessed on 3 November 2020).

104. Graeber, D.; Cerutti, A. Bullshit Jobs; Simon \& Schuster: New York, NY, USA, 2018.

105. Sennett, R. The Corrosion of Character: The Personal Consequences of Work in the New Capitalism; W. W Norton and Co.: London, UK, 1998.

106. Pellegrino, G.; Piva, M.; Vivarelli, M. Are Robots Stealing Our Jobs? IZA Discussion Paper. 2017. No. 10540. Available online: https:/ / ssrn.com/abstract=2911478 (accessed on 15 January 2021).

107. Frey, C.; Osborneb, M. The future of employment: How susceptible are jobs to computerisation? Technol. Forecast. Soc. Change 2017, 114, 254-280. [CrossRef]

108. Markovits, D. The Meritocracy Trap: How America's Foundational Myth Feeds Inequality, Dismantles the Middle Class, and Devours the Elite; Penguin Press: New York, NY, USA, 2019.

109. Daly, H. Economics in a full world. Sci. Am. 2005, 293, 100-107. [CrossRef]

110. Rosa, H. Social Acceleration: Ethical and Political Consequences of a Desynchronized High-Speed Society. Constellations 2003, 10, 3-33. [CrossRef]

111. Rosa, H. Full Speed Burnout? From the Pleasures of the Motorcycle to the Bleakness of the Treadmill: The Dual Face of Social Acceleration. Int. J. Motorcycle Stud. 2010, 6, 1-15.

112. Rosa, H.; Henning, C. Good life beyond growth. An introduction. In The Good Life Beyond Growth. New Perspectives; Rosa, H., Henning, C., Eds.; Routledge: Oxon, UK, 2018.

113. Lindberg, M.; Hylander, J.P. Boundary Dimensions of Social Innovation: Negotiating Conflicts and Compatibilities When Developing a National Agenda. Innov. Eur. J. Soc. Sci. Res. 2016. [CrossRef]

114. Rosa, H.; Henning, C. (Eds.) The Good Life Beyond Growth; Routledge: Oxon, UK, 2018.

115. Rosa, H. Unverfügbarkeit; Residenz Verlag GmbH: Wien Salzburg, Austria, 2018.

116. Rosa, H. Resonanz. Eine Soziologie Der Weltbeziehung; Suhrkamp: Berlin, Germany, 2019.

117. Varoufakis, Y. Austerity; Penguin: London, UK, 2018.

118. Sveiby, K.-E. Innovation and the Global Financial Crisis. Systemic Consequences of Incompetence. In Challenging the Innovation Paradigm; Routledge: New York, NY, USA, 2012; pp. 113-142. 
119. Argyris, C.; Schön, D. Organizational Learning: A Theory of Action Perspective; Addison-Wesley Publishing Company: Reading, PA, USA, 1978; ISBN 0-201-00174-8.

120. Sen, A. The Idea of Justice; Harvard University Press: Cambridge, MA, USA, 2009.

121. Menand, L. Francis Fukuyama Postpones the End of History. The New Yorker. 2018. Available online: https:/ /www.newyorker. $\mathrm{com} / \mathrm{magazine} / 2018 / 09 / 03$ / francis-fukuyama-postpones-the-end-of-history (accessed on 31 October 2020).

122. Stanley, T.; Lee, A. It's Still Not the End of History. The Atlantic. 2014. Available online: https://www.theatlantic.com/politics/ archive/2014/09/its-still-not-the-end-of-history-francis-fukuyama/379394/ (accessed on 31 October 2020).

123. Brancaccio, E.; Giammetti, R.; Lopreite, M.; Puliga, M. Centralization of Capital and Financial Crisis: A Global Network Analysis of Corporate Control. Struct. Chang. Econ. Dyn. 2018, 45, 94-104. [CrossRef]

124. UBS; PwC. Riding the Storm: Market Turbulence Accelerates Diverging Fortunes. UBS Global Wealth Management and PriceWaterhouseCoopers Switzerland. 2020. Available online: https://www.ubs.com/content/dam/static/noindex/wealth-management/ ubs-billionaires-report-2020-spread.pdf (accessed on 15 January 2021).

125. Vitali, S.; Glattfelder, J.; Battinson, S. The Network of Global Corporate Control. PLoS ONE 2011, 6, 1-6. [CrossRef] [PubMed]

126. Rai, A.S. The Affect of Jugaad: Frugal Innovation and Postcolonial Practice in India's Mobile Phone Ecology. Environ. Plan. D Soc. Space 2015, 33, 985-1002. [CrossRef]

127. Skrimizea, E. Scale: The Universal Laws of Growth, Innovation, Sustainability, and the Pace of Life in Organisms, Cities, Economies, and Companies. Plan. Theory 2020. [CrossRef]

128. Boyer, R.H.W. Grassroots Innovation for Urban Sustainability: Comparing the Diffusion Pathways of Three Ecovillage Projects. Environ. Plan. A Econ. Space 2015, 47, 320-337. [CrossRef]

129. Wang, C.C. Geography of Knowledge Sourcing, Search Breadth and Depth Patterns, and Innovative Performance: A Firm Heterogeneity Perspective. Environ. Plan. A Econ. Space 2015, 47, 744-761. [CrossRef]

130. Davies, A.; Fitchett, J. In the Family Way: Bringing a Mother-Daughter (Matrilineal) Perspective to Retail Innovation and Consumer Culture. Environ. Plan. A Econ. Space 2015, 47, 727-743. [CrossRef]

131. Shearmur, R.; Doloreux, D. Central Places or Networks? Paradigms, Metaphors, and Spatial Configurations of Innovation-Related Service Use. Environ. Plan. A Econ. Space 2015, 47, 1521-1539. [CrossRef]

132. Wainwright, T. Circulating Financial Innovation: New Knowledge and Securitization in Europe. Environ. Plan. A Econ. Space 2015, 47, 1643-1660. [CrossRef]

133. Corradini, C.; De Propris, L. Technological Diversification and New Innovators in European Regions: Evidence from Patent Data. Environ. Plan. A Econ. Space 2015, 47, 2170-2186. [CrossRef]

134. Smith, A.; Hargreaves, T.; Hielscher, S.; Martiskainen, M.; Seyfang, G. Making the Most of Community Energies: Three Perspectives on Grassroots Innovation. Environ. Plan. A Econ. Space 2016, 48, 407-432. [CrossRef]

135. Liefner, I.; Jessberger, S. The Use of the Analytical Hierarchy Process as a Method of Comparing Innovation across Regions: The Examples of the Equipment Manufacturing Industries of Shanghai and Xiamen, China. Environ. Plan. A Econ. Space 2016, 48, 1188-1208. [CrossRef]

136. Wainwright, T.; Manville, G. Financialization and the Third Sector: Innovation in Social Housing Bond Markets. Environ. Plan. A 2017, 49, 819-838. [CrossRef]

137. Brinks, V.; Ibert, O.; Müller, F.C.; Schmidt, S. From Ignorance to Innovation: Serendipitous and Purposeful Mobility in Creative Processes-The Cases of Biotechnology, Legal Services and Board Games. Environ. Plan. A Econ. Space 2018, 50, 1742-1763. [CrossRef]

138. Herstad, S.J.; Solheim, M.C.; Engen, M. Learning through Urban Labour Pools: Collected Worker Experiences and Innovation in Services. Environ. Plan. A Econ. Space 2019, 51, 1720-1740. [CrossRef]

139. Fang, L. Agglomeration and Innovation: Selection or True Effect? Environ. Plan. A Econ. Space 2020, 52, 423-448. [CrossRef]

140. Wang, J.; Tan, Y. Social Factory as Prosaic State Space: Redefining Labour in China's Mass Innovation/Mass Entrepreneurship Campaign. Environ. Plan. A Econ. Space 2020, 52, 510-531. [CrossRef]

141. Lehmann, J.-M.; Smets, P. An Innovative Resilience Approach: Financial Self-Help Groups in Contemporary Financial Landscapes in the Netherlands. Environ. Plan. A Econ. Space 2020, 52, 898-915. [CrossRef]

142. Corradini, C. The Geography of Innovation as Reflected by Social Media. Environ. Plan. A Econ. Space 2020, 0308518X2096110. [CrossRef]

143. Cornillie, T.C. Innovation in Public Transport Finance: Property Value Capture, by Shishir Mathur: (2014). Farnham, Surrey, UK: Ashgate. 212 Pages. \$109.95 (Hardcover). J. Am. Plan. Assoc. 2015, 81, 320. [CrossRef]

144. Lindsey, L. Leading the Inclusive City: Place-Based Innovation for a Bounded Planet, by Robin Hambleton: (2015). Chicago, IL: University of Chicago Press. 416 Pages. $\$ 44.95$ (Paperback). J. Am. Plan. Assoc. 2016, 82, 60-61. [CrossRef]

145. Fang, L. Do Clusters Encourage Innovation? A Meta-Analysis. J. Plan. Lit. 2015, 30, 239-260. [CrossRef] 